Prepared in cooperation with the San Luis and Delta Mendota Water Authority

\title{
Dissolved Pesticide Concentrations Entering the Sacramento-San Joaquin Delita from the Sacramento and San Joaquin Rivers, California, 2012-13
}

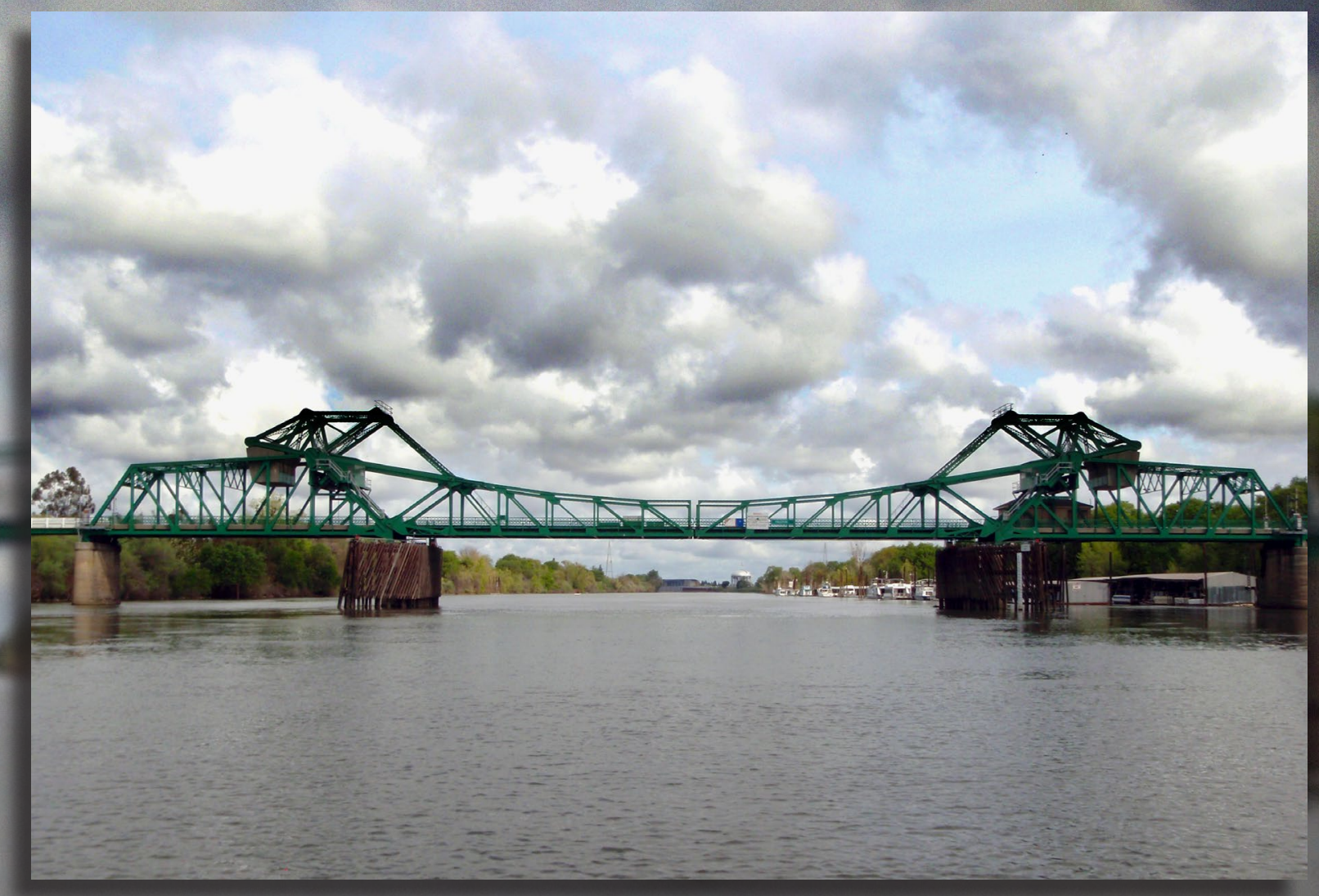

Data Series 876

U.S. Department of the Interior

U.S. Geological Survey 
Cover. View of bridge over the Sacramento River at Freeport, Sacramento, Calif. Photo taken by the author. 


\section{Dissolved Pesticide Concentrations Entering the Sacramento-San Joaquin Delta from the Sacramento and San Joaquin Rivers, California, 2012-13}

By James L. Orlando, Megan McWayne, Corey Sanders, and Michelle Hladik

In cooperation with the San Luis and Delta Mendota Water Authority

Data Series 876 


\title{
U.S. Department of the Interior SALLY JEWELL, Secretary
}

\section{U.S. Geological Survey Suzette M. Kimball, Acting Director}

\author{
U.S. Geological Survey, Reston, Virginia: 2014
}

For more information on the USGS - the Federal source for science about the Earth, its natural and living resources, natural hazards, and the environment, visit http://www.usgs.gov or call 1-888-ASK-USGS.

For an overview of USGS information products, including maps, imagery, and publications, visit http://www.usgs.gov/pubprod

To order this and other USGS information products, visit http://store.usgs.gov

Any use of trade, firm, or product names is for descriptive purposes only and does not imply endorsement by the U.S. Government.

Although this information product, for the most part, is in the public domain, it also may contain copyrighted materials as noted in the text. Permission to reproduce copyrighted items must be secured from the copyright owner.

Suggested citation:

Orlando, J.L., McWayne, Megan, Sanders, Corey, and Hladik, Michelle, 2014, Dissolved pesticide concentrations entering the Sacramento-San Joaquin Delta from the Sacramento and San Joaquin Rivers, California, 2012-13:

U.S. Geological Survey Data Series 876, 28 p., http://dx.doi.org/10.3133/ds876.

ISSN 2327-638X (online) 


\section{Contents}

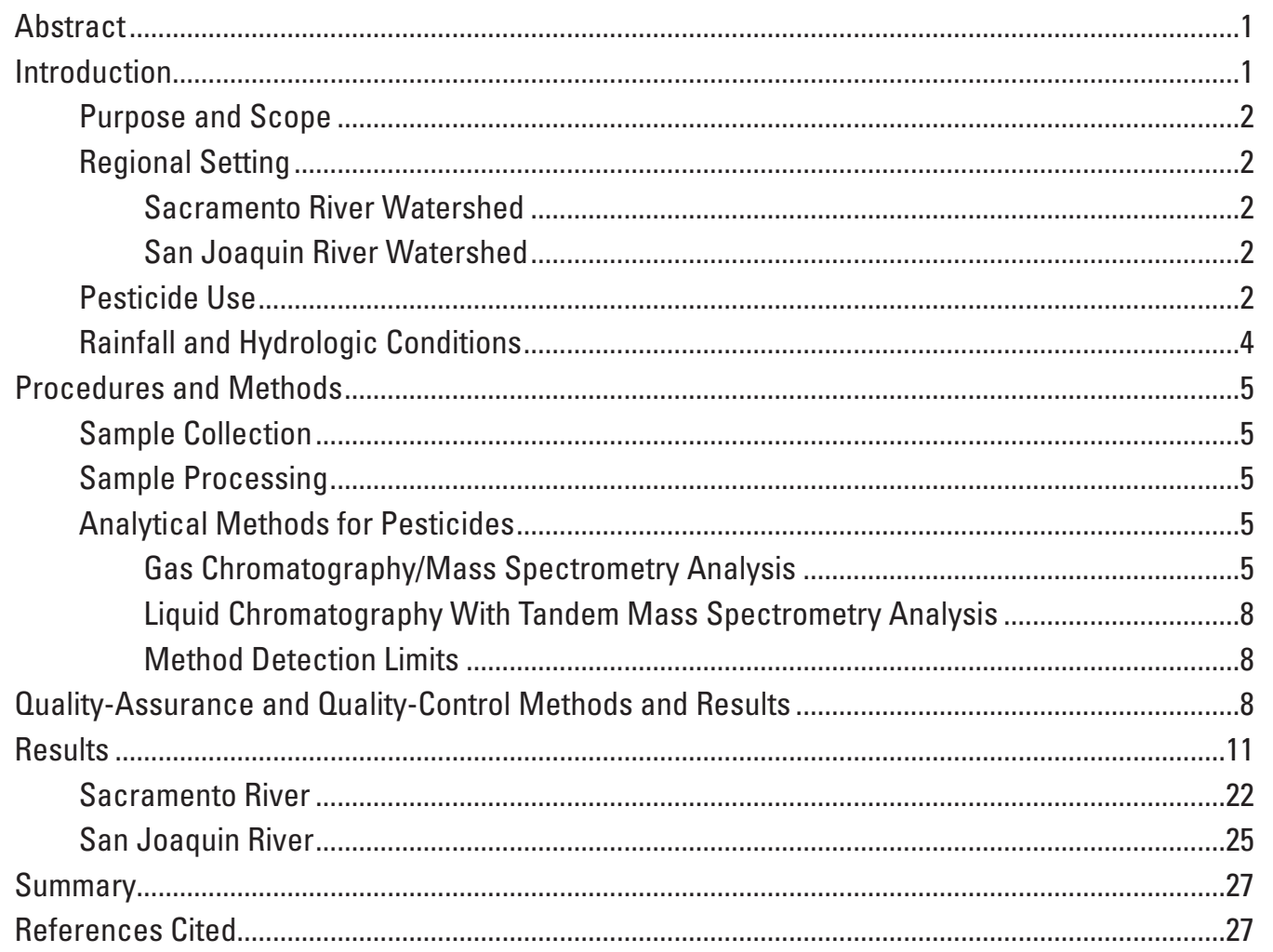




\section{Figures}

1. Map showing locations of sampling sites in the Sacramento-San Joaquin Delta...........3

2. Graph showing daily mean streamflow from U.S. Geological Survey streamgages at Sacramento River at Freeport (11447650), and San Joaquin River near Vernalis (11303500)

3. Graph showing pesticide detection frequencies at the Sacramento River at Freeport, May 2012 through July 2013

4. Graph showing numbers of pesticides detected in Sacramento River samples and San Joaquin River samples, and average daily rainfall in the Central Valley

5. Graph showing concentrations of rice pesticides detected in Sacramento River samples, May 2012 through July 2013

6. Graph showing concentrations of the most frequently detected pesticides in Sacramento River samples, May 2012 through July 2013.

7. Graph showing concentrations of selected pesticides in Sacramento River storm samples collected April 1, 2013, through April 5, 2013, and average daily rainfall in the Sacramento Valley

8. Graph showing pesticide detection frequencies at the San Joaquin River near Vernalis, May 2012 through April 2013

9. Graph showing concentrations of the most frequently detected pesticides in San Joaquin River samples, May 2012 through April 2013 


\section{Tables}

1. Surface-water sampling sites located on the Sacramento and San Joaquin Rivers.......4

2. Method detection limits for pesticides in water measured by the U.S. Geological Survey Organic Chemistry Research Laboratory......

3. Pesticide concentrations measured by gas chromatograph with mass spectrometry in environmental and field replicate water samples from the Sacramento and San Joaquin Rivers, and the relative standard deviations between results

4. Pesticide concentrations measured by liquid chromatography with tandem mass spectrometry in environmental and field replicate water samples from the Sacramento and San Joaquin Rivers, and the relative standard deviations between results

5. Minimum, maximum, and median recovery, and standard deviation of the recoveries, represented as a percentage for all compounds added to laboratory spiked water samples.

6. Pesticide detection frequencies and maximum concentrations measured in environmental water samples collected from the Sacramento and San Joaquin Rivers

7. Pesticide concentrations measured in environmental water samples collected from the Sacramento River, May 2012 through July $2013 .$. .15

8. Pesticide concentrations measured in environmental water samples collected from the San Joaquin River, May 2012 through April 2013

9. Water-quality parameter data measured in water samples collected from the Sacramento and San Joaquin Rivers, May 2012 through July 2013. 


\section{Conversion Factors}

\begin{tabular}{lcl}
\multicolumn{1}{c}{ SI to Inch/Pound } & \multicolumn{1}{c}{ Multiply } & By obtain \\
\hline & Length & \\
\hline millimeter (mm) & 0.03937 & inch (in.) \\
meter (m) & 3.281 & foot (ft) \\
kilometer (km) & 0.6214 & mile (mi) \\
meter (m) & 1.094 & yard (yd) \\
\hline \multicolumn{3}{c}{ Area } \\
\hline millimeter (mm) & 0.03937 & inch (in.) \\
\hline & Volume & \\
\hline liter (L) & 1.057 & quart (qt) \\
\hline & Mass & \\
\hline gram (g) & 0.03527 & ounce, avoirdupois (oz) \\
milligram (mg) & 0.00003527 & ounce, avoirdupois (oz)
\end{tabular}

Inch/Pound to SI

\begin{tabular}{lcl}
\hline \multicolumn{1}{c}{ Multiply } & By & \multicolumn{1}{c}{ To obtain } \\
\hline inch (in.) & Length & \\
foot (ft) & 25.4 & millimeter $(\mathrm{mm})$ \\
mile (mi) & 0.3048 & meter $(\mathrm{m})$ \\
\hline & 1.609 & kilometer $(\mathrm{km})$ \\
\hline square mile $\left(\mathrm{mi}^{2}\right)$ & Area & \\
\hline & 2.590 & square kilometer $\left(\mathrm{km}^{2}\right)$ \\
\hline cubic foot per second $\left(\mathrm{ft}^{3} / \mathrm{s}\right)$ & Flow rate & \\
inch per day (in/d) & 0.02832 & cubic meter per second $\left(\mathrm{m}^{3} / \mathrm{s}\right)$ \\
\hline pound, avoirdupois $(\mathrm{lb})$ & 25.4 & millimeter per day $(\mathrm{mm} / \mathrm{d})$ \\
\hline
\end{tabular}

Temperature in degrees Celsius $\left({ }^{\circ} \mathrm{C}\right)$ may be converted to degrees Fahrenheit $\left({ }^{\circ} \mathrm{F}\right)$ as follows:

${ }^{\circ} \mathrm{F}=\left(1.8 x^{\circ} \mathrm{C}\right)+32$

Horizontal coordinate information is referenced to the North American Datum of 1983 (NAD 83).

Specific conductance is given in microsiemens per centimeter at 25 degrees Celsius $(\mu \mathrm{S} / \mathrm{cm}$ at $\left.25^{\circ} \mathrm{C}\right)$.

Concentrations of chemical constituents in water are given either in milligrams per liter (mg/L) or nanograms per liter (ng/L). 


\section{Abbreviations}

\begin{tabular}{|c|c|}
\hline CDPR & California Department of Pesticide Regulation \\
\hline DCM & dichloromethane \\
\hline DCPMU & $N$-(3,4-Dichlorophenyl)- $N$-methylurea \\
\hline DCPU & 3,4-Dichlorophenylurea \\
\hline $\mathrm{DOC}$ & dissolved organic carbon \\
\hline GC/MS & gas chromatography/mass spectrometry \\
\hline HPLC & high performance liquid chromatography \\
\hline LC/MS/MS & liquid chromatography with tandem mass spectrometry \\
\hline MDL & method detection limit \\
\hline $\mathrm{mL}$ & milliliter \\
\hline $\mathrm{mL} / \mathrm{min}$ & milliliter per minute \\
\hline $\mathrm{mM}$ & millimolar (milimoles per liter of solution) \\
\hline MSD & mass-selective detector \\
\hline NASQAN & National Stream Quality Accounting Network \\
\hline NAWOA & National Water-Quality Assessment \\
\hline $\mathrm{ng} / \mathrm{L}$ & nanograms per liter \\
\hline $\mathrm{ng} / \mu \mathrm{L}$ & nanograms per microliter \\
\hline $\mathrm{QC}$ & quality control \\
\hline SPE & solid-phase extraction \\
\hline SD & standard deviation \\
\hline USGS & U.S. Geological Survey \\
\hline$\mu \mathrm{L}$ & microliter \\
\hline & micrometer \\
\hline
\end{tabular}




\section{Acknowledgments}

This project was funded by the San Luis and Delta Mendota Water Authority, and the U.S. Geological Survey Cooperative Water Program. 


\title{
Dissolved Pesticide Concentrations Entering the Sacramento-San Joaquin Delta from the Sacramento and San Joaquin Rivers, California, 2012-13
}

\author{
By James L. Orlando, Megan McWayne, Corey Sanders, and Michelle Hladik
}

\section{Abstract}

Surface-water samples were collected from the Sacramento and San Joaquin Rivers where they enter the Sacramento-San Joaquin Delta, and analyzed by the U.S. Geological Survey for a suite of 99 current-use pesticides and pesticide degradates. Samples were collected twice per month from May 2012 through July 2013 and from May 2012 through April 2013 at the Sacramento River at Freeport, and the San Joaquin River near Vernalis, respectively. Samples were analyzed by two separate laboratory methods by using gas chromatography with mass spectrometry or liquid chromatography with tandem mass spectrometry. Method detection limits ranged from 0.9 to 10.5 nanograms per liter (ng/L).

A total of 37 pesticides and degradates were detected in water samples collected during the study (18 herbicides, 11 fungicides, 7 insecticides, and 1 synergist). The most frequently detected pesticides overall were the herbicide hexazinone (detected in 100 percent of the samples); 3,4-dichloroaniline (97 percent), which is a degradate of the herbicides diuron and propanil; the fungicide azoxystrobin (83 percent); and the herbicides diuron (72 percent), simazine (66 percent), and metolachlor (64 percent). Insecticides were rarely detected during the study. Pesticide concentrations varied from below the method detection limits to $984 \mathrm{ng} / \mathrm{L}$ (hexazinone).

Twenty seven pesticides and (or) degradates were detected in Sacramento River samples, and the average number of pesticides per sample was six. The most frequently detected compounds in these samples were hexazinone (detected in 100 percent of samples), 3,4-dichloroaniline (97 percent), azoxystrobin (88 percent), diuron (56 percent), and simazine (50 percent). Pesticides with the highest detected maximum concentrations in Sacramento River samples included the herbicide clomazone $(670 \mathrm{ng} / \mathrm{L})$, azoxystrobin (368 ng/L), 3,4-dichloroaniline (364 ng/L), hexazinone (130 ng/L), and propanil (110 ng/L), and all but hexazinone are primarily associated with rice agriculture.

In addition to the twice monthly sampling, surface-water samples were collected from the Sacramento River on 5 consecutive days following a rainfall event in the Sacramento urban area. Samples collected following this event contained an average of 11 pesticides. The insecticides carbaryl, fipronil, and imidacloprid; the herbicide DCPA; and the fungicide imazalil were only detected in the Sacramento River during this storm-runoff event, and two detections of fipronil during this period exceeded the U.S. Environmental Protection Agency Aquatic Life Benchmark (11 ng/L) for chronic toxicity to invertebrates in freshwater.

In San Joaquin River samples, 26 pesticides and (or) degradates were detected, and the average number detected per sample was 9 . The most frequently detected compounds in these samples were hexazinone and metolachlor (detected in 100 percent of samples); diuron (96 percent); the fungicide boscalid (96 percent); the degradates 3,4-dicloroaniline (92 percent) and $N$-(3,4-Dichlorophenyl)- $N$ '-methylurea (DCPMU; 83 percent); simazine (83 percent); and azoxystrobin ( 75 percent). The pesticides with the highest detected maximum concentrations were hexazinone (984 ng/L), diuron (695 ng/L), simazine (524 ng/L), the herbicide prometryn (155 ng/L), metolachlor (127 ng/L), boscalid (112 ng/L), DCPMU (111 ng/L), and the herbicide pendimethalin $(108 \mathrm{ng} / \mathrm{L})$.

\section{Introduction}

The Sacramento-San Joaquin Delta (hereinafter Delta) is an area of critical habitat for numerous species of concern, including chinook salmon and the threatened delta smelt (Sommer and Mejia, 2013). In recent years, multiple pelagic species within the Delta have been in sharp decline (Sommer and others, 2007). The Delta is hydrologically complex, with a great variety of man-made and natural interconnecting sloughs and channels that convey nearly one-half of California's total yearly runoff (California Department of Water Resources, 1993). In addition, the Delta provides water to approximately 25 million people living in southern California and irrigates nearly 750,000 acres of farmland in the southern Central Valley (California Department of Water Resources, 2013a). These factors point to the need for a complete and timely understanding of the quality of water entering the Delta. 
Previous studies have shown that current-use pesticides associated with agricultural and urban runoff enter the Delta from the Sacramento and San Joaquin Rivers throughout the year and that the types and concentrations of these pesticides vary based on their use in the upstream watersheds (Dileanis and others, 2002; Kratzer and others, 2002; Orlando and Kuivila, 2004; Weston and Lydy, 2010; and Zhang and others, 2012). Other studies have suggested that contaminants (including current-use pesticides) may play a role in the decline of pelagic fish species in the Delta (Werner and others, 2010)

This study was conducted by the U.S. Geological Survey (USGS), in cooperation with the San Luis and Delta Mendota Water Authority, to characterize the input of current-use pesticides and pesticide degradates into the Delta from the Sacramento and San Joaquin Rivers, the Delta's two main riverine inputs, during the course of 1 calendar year. Water samples for pesticide analysis were collected twice per month from two sites (Sacramento River at Freeport, and the San Joaquin River near Vernalis) located at the furthest downstream point of each basin before entering the Delta (fig. 1 and table 1). These sites are considered representative integrator sites for the Sacramento and San Joaquin Rivers (Gilliom and others, 1995, Domagalski and others, 1998, Panshin and others, 1998) and have been sampled by the USGS for current-use pesticides since the early 1990s, with investigations performed as part of the National Stream Quality Accounting Network (NASQAN), National WaterQuality Assessment (NAWQA), and Toxics Substances Hydrology programs, as well as in collaboration with numerous State and federal agencies (Orlando, 2013).

\section{Purpose and Scope}

This report describes the methods and procedures used in measuring dissolved pesticide concentrations in filtered surface-water samples collected from the Sacramento and San Joaquin Rivers. Results are presented for a suite of 99 currentuse pesticides and pesticide degradates in surface water.

\section{Regional Setting}

The Delta is an ecologically rich and hydrologically complex region of interconnecting sloughs and channels that receives runoff from a mix of agricultural, urban, and natural sources. The Delta is fed by two primary river systems, the Sacramento River and the San Joaquin River, which flow south and north, respectively, through the Central Valley, and converge in the western Delta (fig. 1). The region is characterized by a Mediterranean climate, with typically wet winters and dry summers. Precipitation falls primarily in the winter and spring as rain in the Central Valley and as snow in the higher elevations of the Sierra Nevada.

\section{Sacramento River Watershed}

The effective Sacramento River watershed upstream from Freeport encompasses over 22,300 square miles $\left(\mathrm{mi}^{2}\right)$ in northern California, and extends from the Delta northward to Oregon border, eastward to the crest of the Sierra Nevada
Mountains, and westward into the Coast Range (fig. 1). The Sacramento River flows southward through the Central Valley where it is joined by a number of major tributaries, and their combined flows enter the Delta at Freeport downstream of Sacramento (fig. 1). Landuse in the watershed is primarily forest in the mountainous upper reaches of the watershed while agriculture dominates within the Central Valley portion of the watershed (roughly $1,980 \mathrm{mi}^{2}$; fig. 1; U.S. Geological Survey, 2014). Major crop types by area are rice, alfalfa, and orchard crops such as almonds, peaches, prunes, and walnuts (Natural Resources Conservation Service, 2013). There are also a number of major urban areas in the watershed. Together these cities cover an area of $445 \mathrm{mi}^{2}$ (fig. 1; U.S. Geological Survey, 2014) and support a population of nearly 2 million, based on the 2010 census (U.S. Census Bureau, 2011). Runoff from agricultural lands, along with discharge from urban waste water treatment plants and storm drains enter the Sacramento River and its tributaries at numerous locations within the watershed.

\section{San Joaquin River Watershed}

The San Joaquin River watershed encompasses over $7,300 \mathrm{mi}^{2}$ in central California and extends southward from the Delta (fig. 1). The San Joaquin River flows northward through the Central Valley where it is joined by a number of major tributaries, and their combined flows enter the Delta near Vernalis (fig. 1). Landuse within the Central Valley is primarily agricultural (over 1,550 $\mathrm{mi}^{2}$ ) while land above the valley floor is primarily shrub, grassland and forest (fig. 1; U.S. Geological Survey, 2014). Major crops grown in the region include cotton, orchard crops and vegetable crops. There are also a number of urban areas in the watershed (fig. 1). Combined these cities cover an area of $170 \mathrm{mi}^{2}$ (U.S. Geological Survey, 2014) and support a population of over 700,000 based on the 2010 census (U.S. Census Bureau, 2011). Runoff from agricultural lands and urban areas enter the San Joaquin River and its tributaries at numerous locations within the watershed.

\section{Pesticide Use}

Agricultural and urban runoff enters the Delta throughout the year from sources upstream from the Delta as well as from agricultural activities and urban waste-water treatment plants within the Delta (California Department of Water Resources, 2013b). These waters can contain current-use pesticides and degradates in concentrations that vary depending in large part on spatial and temporal patterns of pesticide application and hydrologic conditions.

Since 1990, the California Department of Pesticide Regulation (CDPR) has had a full-use reporting system that requires pesticide applicators to provide detailed information on pesticide use. The CDPR system is the most comprehensive pesticide reporting system in the nation, and these data are extremely valuable in assessing trends in pesticide use, changes in application patterns, and potential for environmental contamination. The CDPR reporting system, however, does not contain information on pesticide 


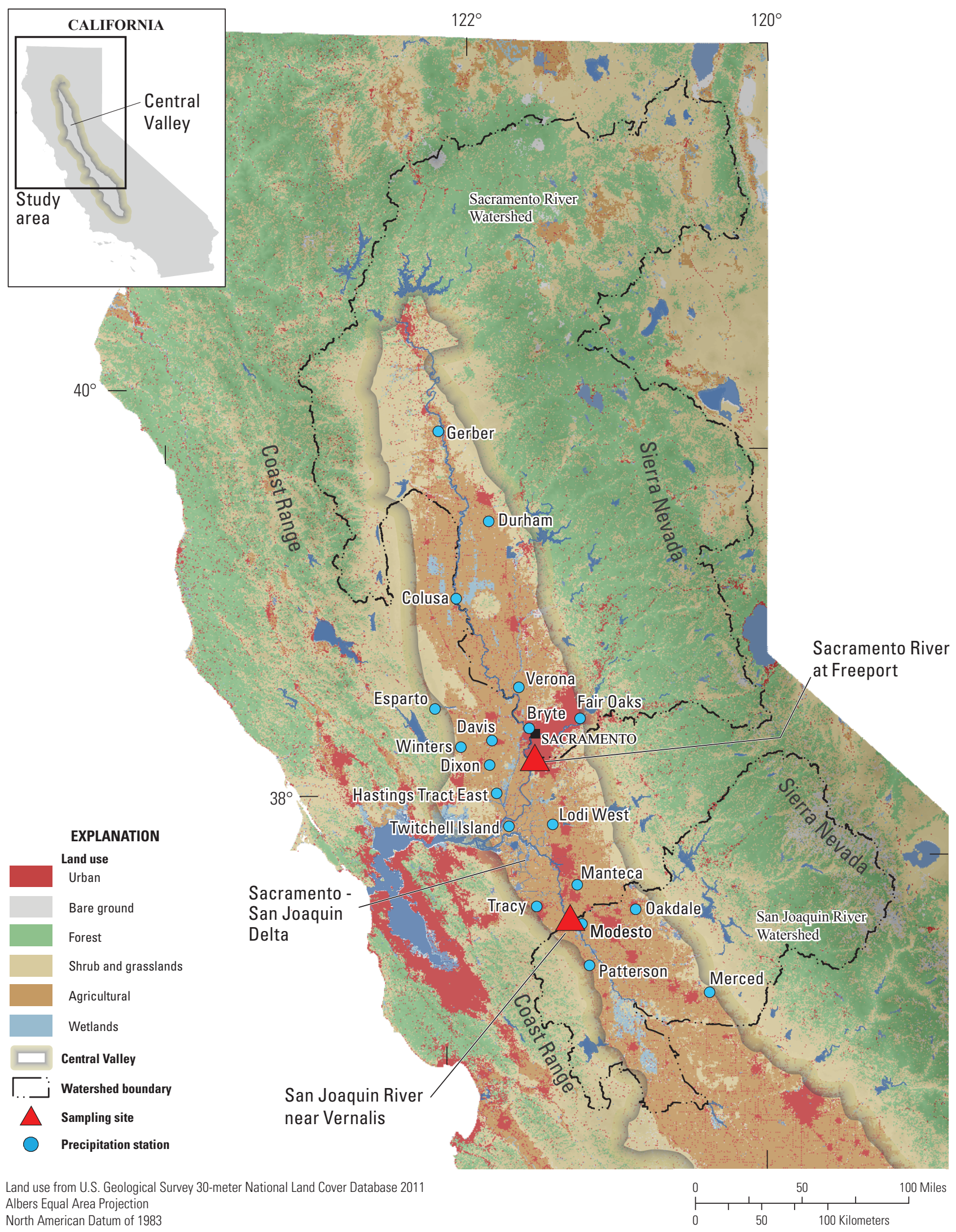

Figure 1. Locations of sampling sites in the Sacramento-San Joaquin Delta. 
Table 1. Surface-water sampling sites located on the Sacramento and San Joaquin Rivers.

[Abbreviations: Calif., California; NAD 83, North American Datum 1983; USGS, U.S. Geological Survey; ㅇ, degrees; ', minutes; ", seconds]

\begin{tabular}{|c|c|c|c|c|c|}
\hline $\begin{array}{c}\text { USGS } \\
\text { station number }\end{array}$ & $\begin{array}{c}\text { USGS } \\
\text { station name }\end{array}$ & Latitude & Longitude & $\begin{array}{l}\text { Horizontal } \\
\text { datum }\end{array}$ & $\begin{array}{l}\text { Period } \\
\text { sampled }\end{array}$ \\
\hline 11447650 & Sacramento River at Freeport, Calif. & $38^{\circ} 27^{\prime} 22^{\prime \prime}$ & $121^{\circ} 30^{\prime} 05^{\prime \prime}$ & NAD 83 & May 2012-July 2013 \\
\hline 11303500 & San Joaquin River near Vernalis, Calif. & $37^{\circ} 40^{\prime} 34^{\prime \prime}$ & $121^{\circ} 15^{\prime} 59^{\prime \prime}$ & NAD 83 & May 2012-April 2013 \\
\hline
\end{tabular}

applications made by homeowners using products purchased at retail stores, which could contribute substantially to total pesticide use in urban areas. In 2012 (the latest year for which data are available), it was reported that over 23.3 million pounds (lb) of pesticides were applied in the Sacramento and San Joaquin River watersheds (9.0 and 14.3 million lbs, respectively; California Department of Pesticide Regulation, 2014). Of this amount, approximately 21.7 million lbs were applied to agricultural land, and approximately 1.6 million lbs were applied by licensed applicators in urban settings.

\section{Rainfall and Hydrologic Conditions}

Pesticide transport is strongly affected by the timing and location of pesticide applications as well as by rainfall and streamflow. Dileanis and others (2003), and Orlando and others (2013) have demonstrated increased pesticide concentrations in surface water following rainfall events in the Sacramento and San Joaquin Valleys that were preceded by pesticide applications.
The California Department of Water Resources classified 2012 and 2013 as "below normal" and "dry" runoff years in the Sacramento Valley, and "dry" and "critical" runoff years in the San Joaquin Valley indicating that the region received well below normal precipitation (California Department of Water Resources, 2013c). Large rainfall events (greater than $1 \mathrm{inch}$ in 24 hours) were rare during the study period in both the Sacramento and San Joaquin valley floor regions. These conditions led to below-normal streamflow on the Sacramento and San Joaquin Rivers where they enter the Delta during most of the study period (U.S. Geological Survey, 2013a, 2013b). Daily mean streamflow measured from May 2012 to July 2013 at two USGS streamgages (Sacramento River at Freeport, 11447650, and San Joaquin River near Vernalis, 11303500) is shown in figure 2. The historic means of daily mean streamflow, based on the periods October 1, 1948, to September 30, 2012, for Sacramento River at Freeport; and October 1, 1923, to September 30, 2012, for San Joaquin River near Vernalis, are shown for comparison (fig. 2).

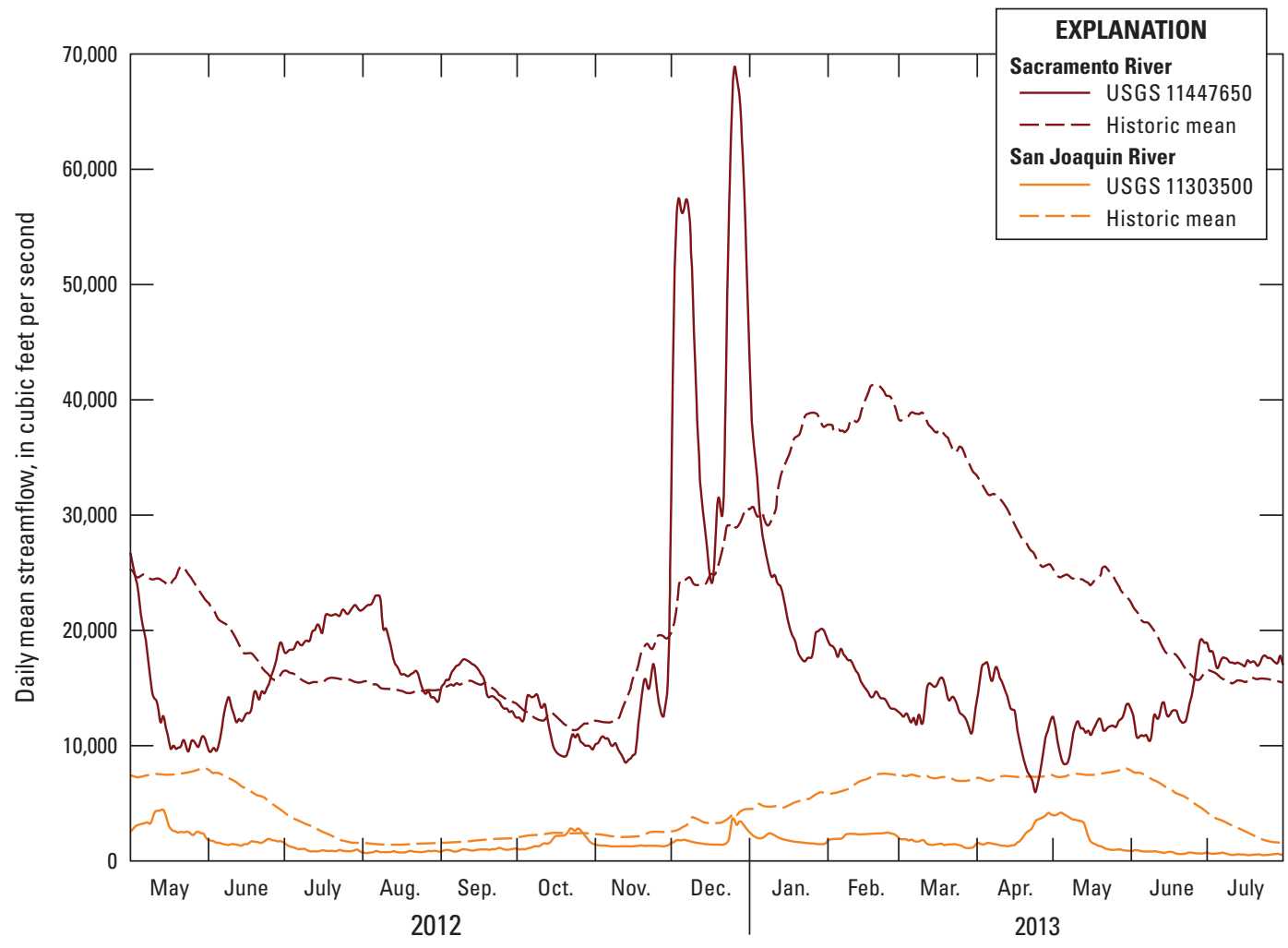

Figure 2. Daily mean streamflow from U.S. Geological Survey (USGS) streamgages at Sacramento River at Freeport (11447650), and San Joaquin River near Vernalis (11303500). 


\section{Procedures and Methods}

Water samples were collected twice per month during 2012 and 2013 from the Sacramento and San Joaquin Rivers where they enter the Delta. Basic field parameters (temperature, specific conductance, $\mathrm{pH}$, and dissolved oxygen concentration) were measured at the time of sample collection. Water samples were transported to the USGS Organic Chemistry Research Laboratory in Sacramento, and analyzed for pesticides using two methods, gas chromatography with mass spectrometry (GC/MS) and liquid chromatography with tandem mass spectrometry (LC/MS/MS) for a suite of 99 current-use pesticides (table 2). Extensive quality-control (QC) sampling was also performed for each method, including field blanks, field replicates, and laboratory matrix-spike and matrix-spike-replicate samples. The procedures and methods for this study included sample-collection methods in the field, sample-processing methods in the laboratory, and analytical methods for pesticides.

\section{Sample Collection}

Surface-water samples were collected from the Sacramento River at Freeport and the San Joaquin River near Vernalis twice per month from May 2012 to July 2013, and from May 2012 to April 2013, respectively (table 1). Samples were also collected from the Sacramento River at Freeport for 5 consecutive days (April 1 through April 5, 2013) following a moderate rainfall event (greater than 0.5 inches in 24 hours) in the Sacramento urban area. At the Sacramento River site all samples were collected from a boat as integrated grab samples using a US D-96 depth-integrating sampler configured with a Teflon nozzle and 3 liter (L) Teflon-lined collection bag following methods described by the Federal Interagency Sedimentation Project (2002). Sample water was obtained at five locations equally spaced across the stream channel on the ebb tide following standard USGS sampling procedures (U.S. Geological Survey, 2006). Sample water was poured into a Teflon churn splitter following collection at each location. The churn was placed on ice after all sample water was collected and delivered to the USGS Organic Chemistry Research Laboratory in Sacramento, Calif., for processing and analysis.

At the San Joaquin River site surface-water samples were collected from a bridge at 15-20 equally spaced points across the stream channel using a US DH-95 depthintegrating sampler (Federal Interagency Sedimentation Project, 2000) following standard USGS sampling procedures (U.S. Geological Survey, 2006). Sample water was collected in a 1-L Teflon collection bottle and poured into a Teflon churn splitter. After water from all sampling points had been collected, sample water was churned into 1-L amber glass bottles that were then placed on ice for transport to the USGS Organic Chemistry Research Laboratory in Sacramento, Calif., for further processing and analysis.
Prior to all sampling events, the sampler nozzle, bag or bottle, and churn were cleaned with tap water and soap, triple rinsed with organic-free deionized water, and rinsed with reagent grade methanol. All components were then allowed to air dry and stored in sealed plastic bags. On arrival at the sampling site, all equipment was triple rinsed with native water prior to sample collection. During sample collection, basic water parameters (temperature, $\mathrm{pH}$, specific conductance, and dissolved oxygen concentration) were measured at a depth of approximately 2 feet (ft) at the center of the channel using a multiparameter meter (YSI model 6920 V2), which was calibrated with appropriate standards and buffers prior to sampling.

\section{Sample Processing}

Sample processing was performed in the laboratory within 24 hours of sample collection. All water samples were filtered through 0.7 -micrometer $(\mu \mathrm{m})$ glass-fiber filters (Grade GF/F, Whatman, Piscataway, New Jersey) into precleaned glass bottles to remove suspended material. Samples were then stored refrigerated at 2 degrees Celsius $\left({ }^{\circ} \mathrm{C}\right)$ until analysis.

\section{Analytical Methods for Pesticides}

Analytical instruments were calibrated with standards in concentrations that spanned the linear range of instrument response ( 0.025 to 2.5 nanograms per microliter $[\mathrm{ng} / \mu \mathrm{L}])$. Calibration curves were determined by linear regression and considered acceptable if the coefficient of determination $\left(\mathrm{R}^{2}\right)$ for each compound was greater than 0.995 . The responses of the instruments were monitored every $6-8$ samples with a mid-level check standard of $0.25 \mathrm{ng} / \mu \mathrm{L}$ or $0.5 \mathrm{ng} / \mu \mathrm{L}$. The instruments were considered to be stable if the recoveries of the check standards fell within the range of 80-120 percent of the nominal standard concentration. All environmental sample concentrations fell within the linear range of the instruments.

\section{Gas Chromatography/Mass Spectrometry Analysis}

GC/MS analysis methods were based on those previously described by Hladik and others $(2008,2009)$. To summarize these methods, each 1-L filtered-water sample was spiked with ${ }^{13} \mathrm{C}_{3}$-atrazine (Cambridge Isotopes, Andover, Massachusetts) as a recovery surrogate. The sample was then pumped under vacuum at a flow rate of 10 milliliters per minute $(\mathrm{mL} / \mathrm{min})$ through an Oasis HLB solid-phase extraction (SPE) cartridge (6 milliliters [mL], 500 milligrams [mg], $60 \mu \mathrm{m}$, Waters Corporation, Milford, Massachusetts) that had been cleaned with two column-volumes of ethyl acetate followed by two column-volumes of methanol and two columnvolumes of organic-free deionized water. After extraction, approximately 1 gram $(\mathrm{g})$ of sodium sulfate $\left(\mathrm{Na}_{2} \mathrm{SO}_{4}\right)$ was 
Table 2. Method detection limits for pesticides in water measured by the U.S. Geological Survey Organic Chemistry Research Laboratory.

[Abbreviations: GC/MS, gas chromatograph with mass spectrometry; LC/MS/MS, liquid chromatography with tandem mass spectrometry; ng/L, nanograms per liter; NWIS, National Water Information System]

\begin{tabular}{|c|c|c|c|c|c|}
\hline Compound & $\begin{array}{c}\text { NWIS } \\
\text { parameter } \\
\text { code }\end{array}$ & $\begin{array}{c}\text { Chemical } \\
\text { class }\end{array}$ & $\begin{array}{c}\text { Pesticide } \\
\text { type }\end{array}$ & $\begin{array}{c}\text { Method } \\
\text { detection limit } \\
\text { (ng/L) }\end{array}$ & $\begin{array}{l}\text { Analytical } \\
\text { method }\end{array}$ \\
\hline Acetamiprid & 68302 & Neonicotinoid & Insecticide & 3.6 & $\mathrm{LC} / \mathrm{MS} / \mathrm{MS}$ \\
\hline Alachlor & 65064 & Chloroacetanilide & Herbicide & 1.7 & GC/MS \\
\hline Allethrin & 66586 & Pyrethroid & Insecticide & 6.0 & $\mathrm{GC} / \mathrm{MS}$ \\
\hline Atrazine & 65065 & Triazine & Herbicide & 2.3 & $\mathrm{GC} / \mathrm{MS}$ \\
\hline Boscalid & 67550 & Pyridine & Fungicide & 2.8 & $\mathrm{GC} / \mathrm{MS}$ \\
\hline Butylate & 65068 & Thiocarbamate & Herbicide & 1.8 & $\mathrm{GC} / \mathrm{MS}$ \\
\hline Carbaryl & 65069 & Carbamate & Insecticide & 6.5 & $\mathrm{GC} / \mathrm{MS}$ \\
\hline Carbofuran & 65070 & Carbamate & Insecticide & 3.1 & $\mathrm{GC} / \mathrm{MS}$ \\
\hline Chlorothalonil & 65071 & Chloronitrile & Fungicide & 4.1 & GC/MS \\
\hline Cyfluthrin & 65074 & Pyrethroid & Insecticide & 5.2 & $\mathrm{GC} / \mathrm{MS}$ \\
\hline Cyhalothrin & 68354 & Pyrethroid & Insecticide & 4.5 & $\mathrm{GC} / \mathrm{MS}$ \\
\hline Cypermethrin & 65075 & Pyrethroid & Insecticide & 5.6 & $\mathrm{GC} / \mathrm{MS}$ \\
\hline Cyproconazole & 66593 & Triazole & Fungicide & 4.7 & $\mathrm{GC} / \mathrm{MS}$ \\
\hline Cyprodinil & 67574 & Pyrimidine & Fungicide & 7.4 & GC/MS \\
\hline DCPA & 65076 & Benzenedicarboxylic acid & Herbicide & 2.0 & $\mathrm{GC} / \mathrm{MS}$ \\
\hline$p, p^{\prime}-\mathrm{DDD}$ & 65094 & Organochlorine & Degradate & 4.1 & GC/MS \\
\hline$p, p^{\prime}-\mathrm{DDE}$ & 65095 & Organochlorine & Degradate & 3.6 & GC/MS \\
\hline$p, p^{\prime}-\mathrm{DDT}$ & 65096 & Organochlorine & Insecticide & 4.0 & GC/MS \\
\hline Deltamethrin & 65077 & Pyrethroid & Insecticide & 3.5 & GC/MS \\
\hline Desulfinylfipronil & 66607 & Phenylpyrazole & Degradate & 1.6 & GC/MS \\
\hline Diuron & 66598 & Urea & Herbicide & 3.2 & $\mathrm{LC} / \mathrm{MS} / \mathrm{MS}$ \\
\hline Esfenvalerate & 65081 & Pyrethroid & Insecticide & 3.9 & GC/MS \\
\hline Ethalfluralin & 65082 & Aniline & Herbicide & 3.0 & GC/MS \\
\hline Etofenprox & 67604 & Pyrethroid & Insecticide & 2.2 & GC/MS \\
\hline$S$-Ethyl dipropylthiocarbamate (EPTC) & 65080 & Thiocarbamate & Herbicide & 1.5 & GC/MS \\
\hline Famoxadone & 67609 & Oxazole & Fungicide & 2.5 & GC/MS \\
\hline Fenarimol & 67613 & Pyrimidine & Fungicide & 6.5 & GC/MS \\
\hline Fenbuconazole & 67618 & Triazole & Fungicide & 5.2 & GC/MS \\
\hline Fenhexamide & 67622 & Anilide & Fungicide & 7.6 & GC/MS \\
\hline Fenpropathrin & 65083 & Pyrethroid & Insecticide & 4.1 & GC/MS \\
\hline Fipronil & 66604 & Phenylpyrazole & Insecticide & 2.9 & GC/MS \\
\hline Fipronil sulfide & 66610 & Phenylpyrazole & Degradate & 1.8 & GC/MS \\
\hline Fipronil sulfone & 66613 & Phenylpyrazole & Degradate & 3.5 & GC/MS \\
\hline Fluazinam & 67636 & Pyridine & Fungicide & 4.4 & GC/MS \\
\hline Fludioxinil & 67640 & Pyrrole & Fungicide & 7.3 & GC/MS \\
\hline Fluoxastrobin & 67645 & Strobilurin & Fungicide & 4.2 & GC/MS \\
\hline
\end{tabular}


Table 2. Method detection limits for pesticides in water measured by the U.S. Geological Survey Organic Chemistry Research Laboratory.-Continued

[Abbreviations: GC/MS, gas chromatograph with mass spectrometry; LC/MS/MS, liquid chromatography with tandem mass spectrometry; ng/L, nanograms per liter; NWIS, National Water Information System]

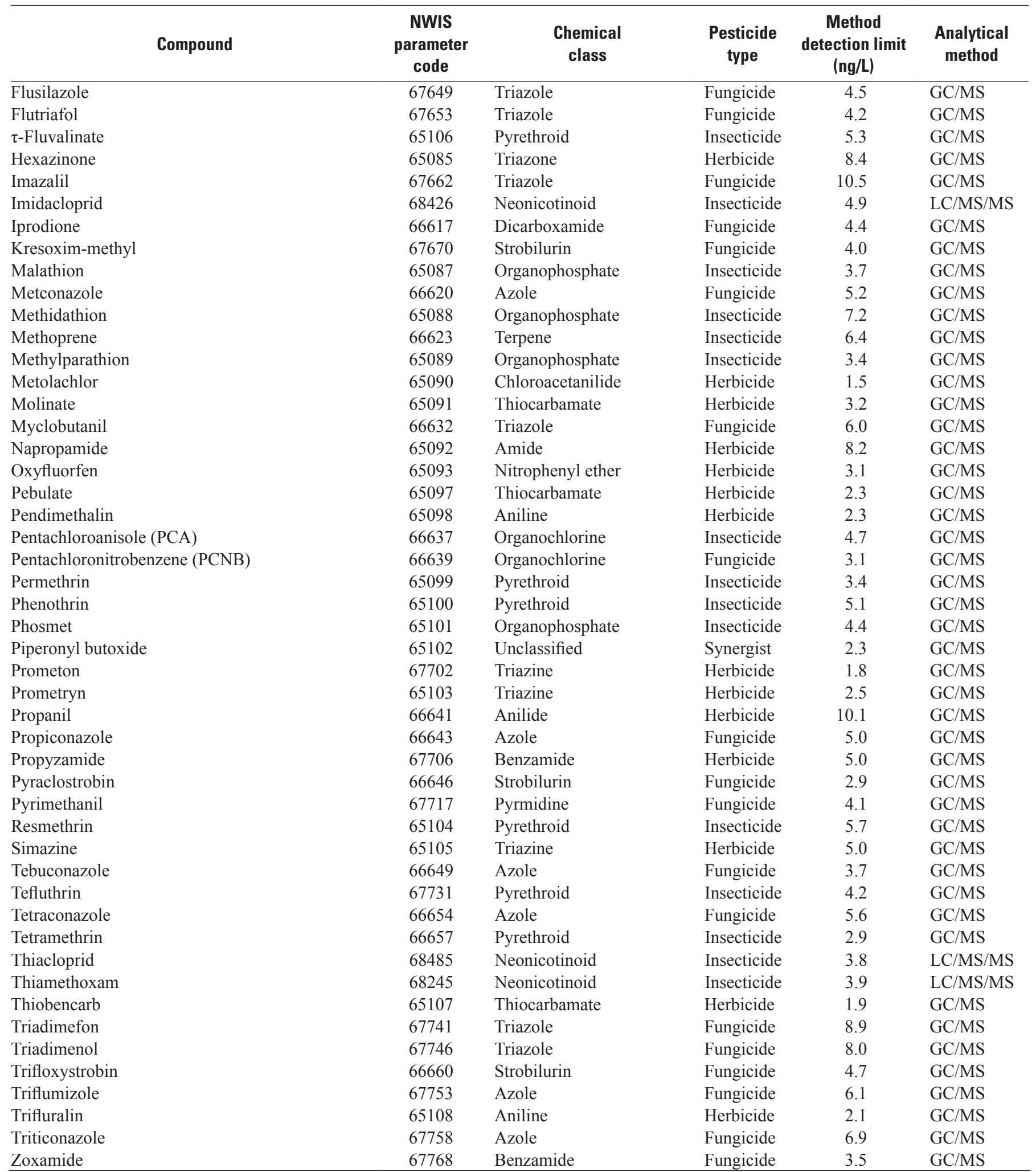


added to the sample bottle to remove any residual water, and the bottles were rinsed three times with approximately $2 \mathrm{~mL}$ of dichloromethane (DCM) into a collection tube. The bottle rinses were concentrated to $1 \mathrm{~mL}$ under a gentle stream of nitrogen gas. Each cartridge was dried on a manifold by passing carbon dioxide through the cartridge for approximately 1 hour or until the SPE sorbent was dry. Each cartridge was then eluted with $12 \mathrm{~mL}$ of ethyl acetate, and the eluate was combined with its corresponding bottle rinse. The combined solution was then reduced under a gentle stream of dry nitrogen to a final volume of 200 microliters $(\mu \mathrm{L})$ for analysis. An internal standard ( $20 \mu \mathrm{L}$ of 2 nanograms per liter $[\mathrm{ng} / \mathrm{L}]$ ) containing the deuterated polycyclic aromatic hydrocarbon compounds acenaphthene- $d_{10}$ and pyrene- $d_{10}$ was then added to each sample. The sample extracts were stored (not to exceed 30 days) in a freezer at $-20{ }^{\circ} \mathrm{C}$ until instrumental analysis.

Water extracts were analyzed for 89 current-use pesticides on an Agilent 7890A GC chromatograph with an Agilent 5975C Inert XL EI mass-selective detector (MSD) system using a DB-5MS analytical column (30 meter [m] by 0.25 millimeter [mm] by $0.25 \mu \mathrm{m}$, Agilent, Palo Alto, Calif.) for separation and helium as the carrier gas. Data were collected in the selected-ion-monitoring mode. Additional details of the GC/MS method can be found in Hladik and others $(2008,2009)$.

One sample (Sacramento River at Freeport, June 26, 2013) to be analyzed by GC/MS was lost during laboratory processing, and no results are available for pesticides measured by GC/MS, although the same environmental sample was analyzed by LC/MS/MS, and those results are reported.

\section{Liquid Chromatography With Tandem Mass Spectrometry Analysis}

Each 1-L filtered-water sample was spiked with the recovery surrogate standards monuron (Chem Service, West Chester, Pennsylvania) and imidacloprid- $d_{4}$ (Cambridge Isotope Laboratories, Andover, Massachusetts). The sample was then pumped under vacuum at a flow rate of $10 \mathrm{~mL} / \mathrm{min}$ through an Oasis HLB SPE ( $6 \mathrm{~mL}, 500 \mathrm{mg}, 60 \mu \mathrm{m}$, Waters Corporation, Milford, Massachusetts) cartridge that had been cleaned with one column-volume of DCM, followed by one column-volume of acetone and two column-volumes of deionized water. The SPE cartridge was then dried using a stream of carbon dioxide for approximately 1 hour or until the SPE sorbent was dry. The cartridges were eluted into a clean, glass concentrator tube by using $10 \mathrm{~mL}$ of a solution of 1 DCM:1 acetone. The eluent was evaporated to less than $0.5 \mathrm{~mL}$ in a fume hood under a gentle stream of nitrogen, then solvent-exchanged into acetonitrile and further evaporated to $200 \mu \mathrm{L}$. The internal standard $\left({ }^{13} \mathrm{C}_{3}\right.$-caffeine, Cambridge Isotope Laboratories) was then added ( $10 \mu \mathrm{L}$ of a $1-n g / \mu \mathrm{L}$ solution). The sample extracts were stored (not to exceed 30 days) in a freezer at $-20^{\circ} \mathrm{C}$ until analysis.
Water extracts were analyzed for the herbicide diuron, three diuron degredates (DCPMU, 3,4-Dichlorophenylurea (DCPU), and 3,4-dichloroaniline), and six neonicotinoid insecticides (acetamiprid, clothianidin, dinotefuran, imidacloprid, thiacloprid, and thiamethoxam) by LC/MS/MS. Aliquots of the sample extracts $(10 \mu \mathrm{L})$ were injected, and the compounds were separated on an Agilent (Palo Alto, Calif.) 1100 Series high performance liquid chromatograph (HPLC) coupled to a 6430 tandem mass spectrometry (MS)system with a Zorbax Eclipse XDB-C18 column $(2.1 \mathrm{~mm}$ by $150 \mathrm{~mm}$ by $3.5 \mathrm{~mm}$, Agilent). The mobile phases were acetonitrile (A channel) and 5 millimolar (mM) formic acid in water (B channel). Data were collected in the multiple-reactionmonitoring mode. Additional details of the LC/MS/MS analytical method can be found in Hladik and Calhoun (2012).

\section{Method Detection Limits}

Method detection limits (MDL) for surface-water samples were validated in previous studies (Hladik and others, 2008; Hladik and Calhoun, 2012) by using the procedure described in 40 CFR Part 136 appendix B (U.S. Environmental Protection Agency, 1992). MDLs for pesticides in surface water ranged from 0.9 to $10.5 \mathrm{ng} / \mathrm{L}$ (table 2). Analytes can sometimes be identified at concentrations less than the MDLs with lower confidence in the numerical value; therefore, concentrations of compounds detected below the MDLs are reported as estimates.

\section{Quality-Assurance and Quality-Control Methods and Results}

Pesticide concentrations were validated against a comprehensive set of performance based QC criteria, including field blanks, field replicates, laboratory matrix-spike and matrix spike-replicate samples, and surrogate recoveries. QC samples were analyzed using the GC/MS and LC/MS/MS methods described earlier.

During the study, six field blanks consisting of pesticidegrade organic-free blank water were processed to test the cleanliness of the field procedures. Field blanks were processed in the same manner as the environmental samples. Blank samples were analyzed using both the GC/MS and LC/MS/MS methods. No pesticides were detected in any of the field blanks, so no results are shown.

Twelve field replicate sample pairs were analyzed ( 7 by GC/MS and 5 by LC/MS/MS; tables 3 and 4 ) to test the reproducibility of results, and there were 49 paired detections of pesticides. The relative standard deviations between replicate samples were less than the control limit of 25 percent in all cases (tables 3 and 4). There were no instances where a pesticide was detected in either the environmental or replicate sample and not in the corresponding sample (tables 3 and 4). 

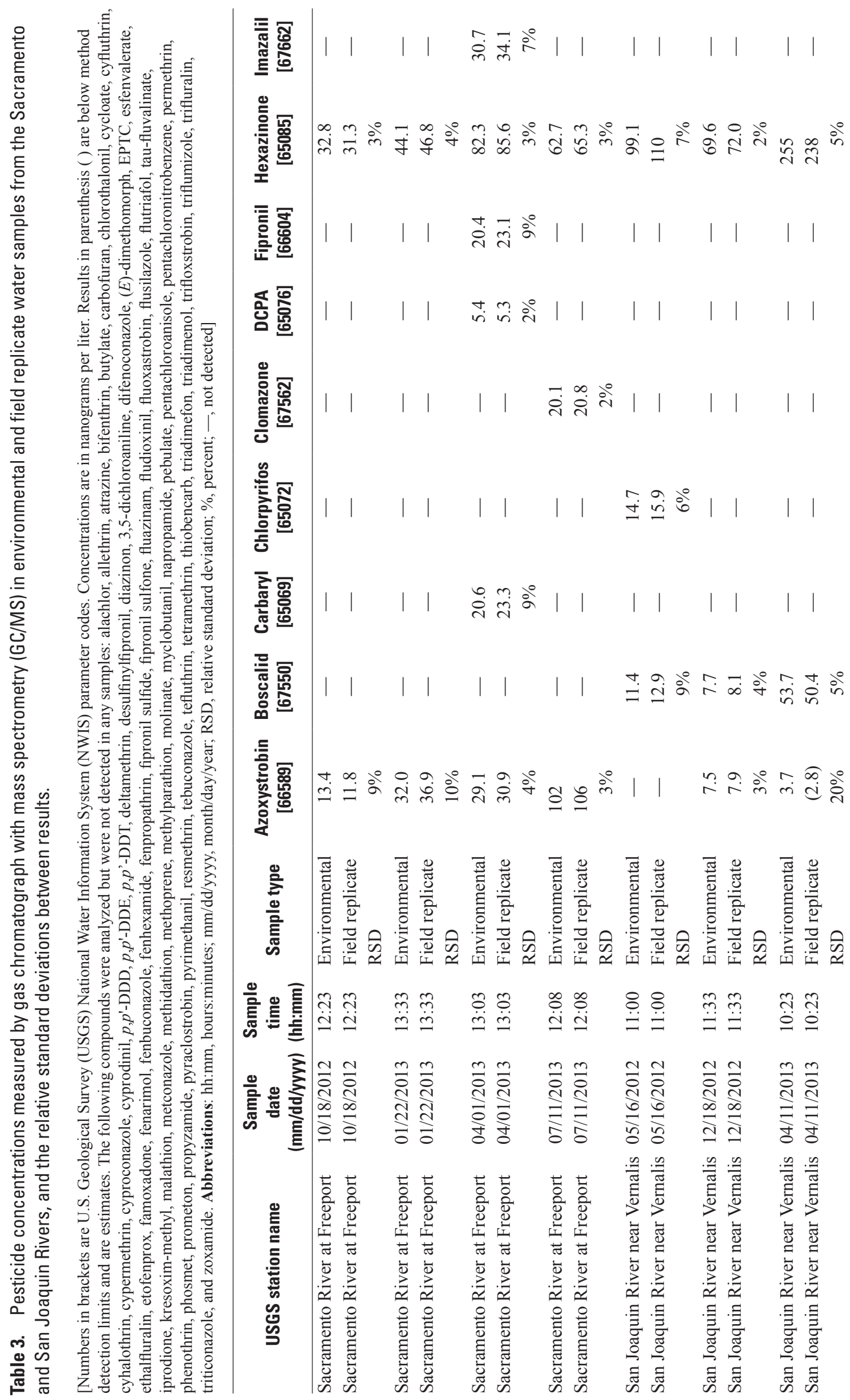


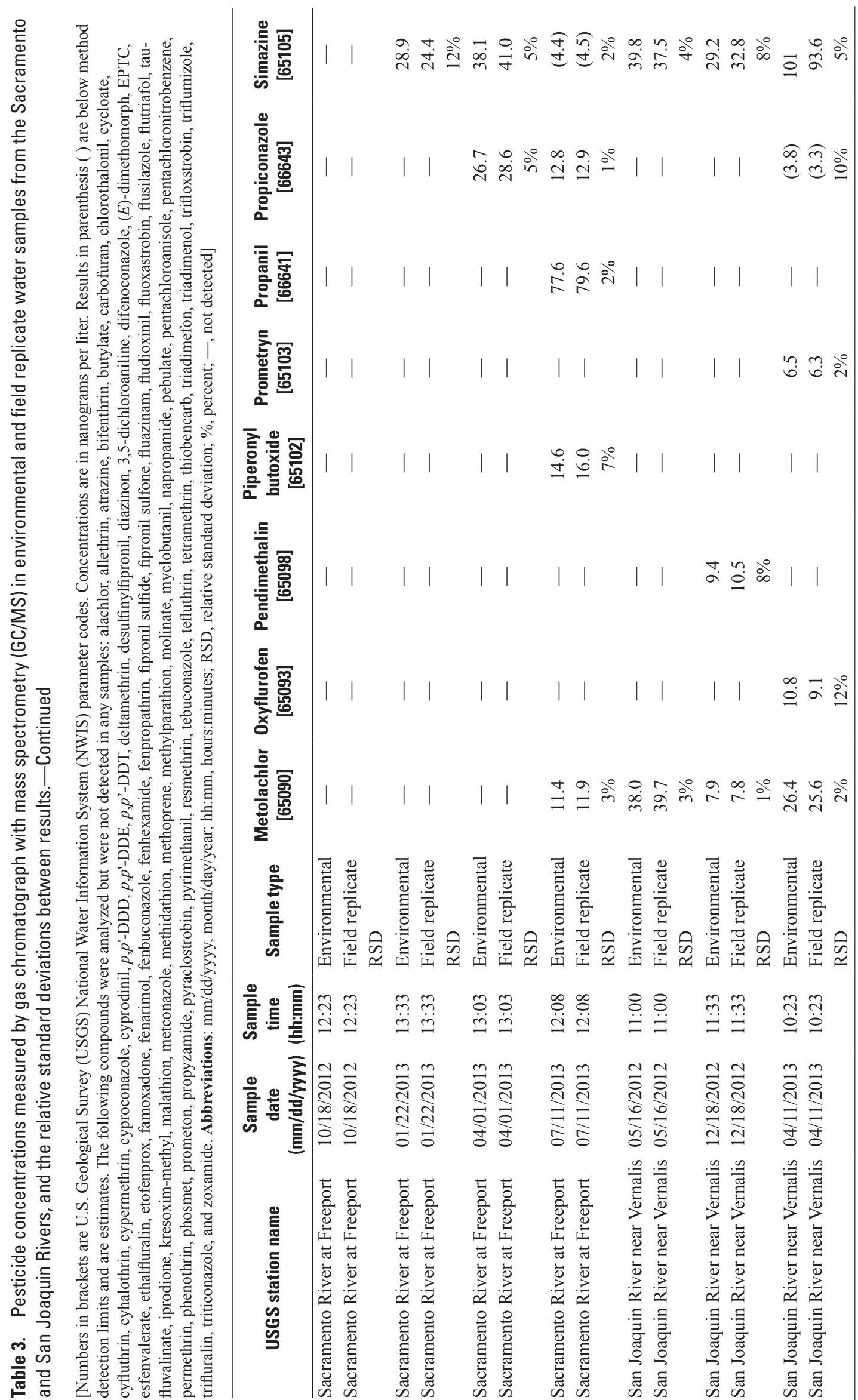


Table 4. Pesticide concentrations measured by liquid chromatography with tandem mass spectrometry (LC/MS/MS) in environmental and field replicate water samples from the Sacramento and San Joaquin Rivers, and the relative standard deviations between results.

[Numbers in brackets are U.S Geological Survey (USGS) National Water Information System (NWIS) parameter codes. Concentrations are in nanograms per liter. Results in parenthesis ( ) are below method detection limits and are estimates. The following compounds were analyzed but were not detected in any samples: acetamiprid, clothianidin, DCPU, dinotefuran, imidacloprid, thiacloprid, and thiamethoxam. Abbreviations: hh:mm, hours:minutes; mm/dd/yyyy, month/day/year; RSD, relative standard deviation; \%, percent; - , not detected]

\begin{tabular}{|c|c|c|c|c|c|c|}
\hline USGS station name & $\begin{array}{c}\text { Sample } \\
\text { date } \\
\text { (mm/dd/yyyy) }\end{array}$ & $\begin{array}{l}\text { Sample time } \\
\text { (hh:mm) }\end{array}$ & Sample type & $\begin{array}{c}\text { 3,4-Dichloroaniline } \\
\text { [66584] }\end{array}$ & $\begin{array}{l}\text { DCPMU } \\
\text { [68231] }\end{array}$ & $\begin{array}{l}\text { Diuron } \\
\text { [66598] }\end{array}$ \\
\hline Sacramento River at Freeport & 08/07/2012 & 11:05 & Environmental & 50.5 & - & - \\
\hline \multirow[t]{2}{*}{ Sacramento River at Freeport } & $08 / 07 / 2012$ & 11:05 & Field replicate & 43.2 & - & - \\
\hline & & & RSD & $11 \%$ & & \\
\hline Sacramento River at Freeport & $11 / 27 / 2012$ & 11:03 & Environmental & 60.8 & - & 7.9 \\
\hline \multirow[t]{2}{*}{ Sacramento River at Freeport } & $11 / 27 / 2012$ & 11:03 & Field replicate & 58.1 & - & 7.5 \\
\hline & & & RSD & $3 \%$ & & $4 \%$ \\
\hline Sacramento River at Freeport & $02 / 19 / 2013$ & 09:53 & Environmental & 9.4 & - & - \\
\hline \multirow[t]{2}{*}{ Sacramento River at Freeport } & $02 / 19 / 2013$ & 09:53 & Field replicate & 10.0 & - & - \\
\hline & & & RSD & $4 \%$ & & \\
\hline San Joaquin River near Vernalis & $07 / 02 / 2012$ & $12: 00$ & Environmental & 5.2 & 17.2 & 19.2 \\
\hline \multirow[t]{2}{*}{ San Joaquin River near Vernalis } & $07 / 02 / 2012$ & 12:00 & Field replicate & 5.9 & 19.8 & 20.7 \\
\hline & & & RSD & $9 \%$ & $10 \%$ & $5 \%$ \\
\hline San Joaquin River near Vernalis & $10 / 30 / 2012$ & $10: 48$ & Environmental & $(2.3)$ & - & $(3.1)$ \\
\hline \multirow[t]{2}{*}{ San Joaquin River near Vernalis } & $10 / 30 / 2012$ & $10: 48$ & Field replicate & $(2.2)$ & - & (2.8) \\
\hline & & & RSD & $3 \%$ & & $7 \%$ \\
\hline
\end{tabular}

Eleven laboratory matrix-spike samples paired with 11 matrix-spike-replicate samples were analyzed ( 5 by GC/MS and 6 by LC/MS/MS; table 5) to assess pesticide recovery, degradation, sorption, and potential interferences caused by the sampling matrix. Percent recoveries for all pesticides in all 22 samples met the data-quality objective of 70 to 130 percent (table 5). These 11 pairs of laboratory matrixspike and matrix-spike-replicate samples were also tested for reproducibility, and the relative standard deviations were less than the control limit of 25 percent in all cases (table 5). Minimum, maximum, and median recoveries and standard deviations of these recoveries for all pesticides are shown in table 5 .

To assess the efficiency of sample extraction for the $\mathrm{GC} / \mathrm{MS}$ and $\mathrm{LC} / \mathrm{MS} / \mathrm{MS}$ analytical methods, ring- ${ }^{13} \mathrm{C}_{3}$-atrazine and diethyl- $\mathrm{d}_{10}$ diazinon, and monuron and imidacloprid- $\mathrm{d}_{4}$, respectively, were used as recovery surrogates. Percentage recoveries of surrogates for all samples analyzed (including QC samples) met the data-quality objective of 70 to 130 percent.

\section{Results}

A total of 37 pesticides or pesticide degradates (table 6) were detected in water samples collected from the Sacramento and San Joaquin Rivers during this study, and each sample contained a mixture of at least 3 compounds. The most frequently detected pesticides overall were the herbicide hexazinone (100 percent); 3,4-dichloroaniline (97 percent); which is a degradate of the herbicides diuron and propanil; the fungicide azoxystrobin ( 83 percent); and the herbicides diuron (72 percent), simazine (66 percent), and metolachlor (64 percent; table 6). Concentrations ranged from below method detection limits to $984 \mathrm{ng} / \mathrm{L}$ (hexazinone; tables 6, 7, and 8).

To provide context for the pesticide concentration data collected during this study, results from the field measurements of the water-quality parameters (water temperature, specific conductance, dissolved oxygen, and $\mathrm{pH}$ ) are provided in table 9 . 


\section{Dissolved Pesticide Concentrations Entering the Sacramento-San Joaquin Delta}

Table 5. Minimum, maximum, and median recovery, and standard deviation of the recoveries, represented as a percentage for all compounds added to laboratory spiked water samples.

[Five spiked samples and five spiked replicate samples were analyzed by gas chromatography with mass spectrometry (GC/MS). Compounds noted with ** were analyzed in six spiked samples and six spiked replicate samples by liquid chromatography with tandem mass spectrometry (LC/MS/MS). Abbreviations: $\%$, percent; \pm , plus or minus]

\begin{tabular}{|c|c|c|c|c|}
\hline Compound & $\begin{array}{l}\text { Minimum recovery } \\
\text { (in percent) }\end{array}$ & $\begin{array}{l}\text { Maximum recovery } \\
\quad \text { (in percent) }\end{array}$ & $\begin{array}{l}\text { Median recovery } \\
\text { (in percent) }\end{array}$ & $\begin{array}{l}\text { Standard deviation } \\
\text { (in percent) }\end{array}$ \\
\hline Acetamiprid** & 74 & 113 & 88 & \pm 11 \\
\hline Alachlor & 93 & 110 & 99 & \pm 5 \\
\hline Allethrin & 83 & 110 & 93 & \pm 8 \\
\hline Atrazine & 82 & 113 & 100 & \pm 10 \\
\hline Azoxystrobin & 79 & 109 & 98 & \pm 9 \\
\hline Bifenthrin & 85 & 100 & 92 & \pm 5 \\
\hline Boscalid & 75 & 111 & 102 & \pm 11 \\
\hline Butylate & 79 & 101 & 89 & \pm 7 \\
\hline Carbaryl & 78 & 108 & 95 & \pm 11 \\
\hline Carbofuran & 79 & 110 & 100 & \pm 11 \\
\hline Chlorothalonil & 73 & 103 & 84 & \pm 10 \\
\hline Chlorpyrifos & 74 & 101 & 91 & \pm 8 \\
\hline Clomazome & 90 & 109 & 99 & \pm 6 \\
\hline Clothianidin** & 74 & 95 & 82 & \pm 7 \\
\hline Cycloate & 86 & 117 & 99 & \pm 9 \\
\hline Cyfluthrin & 81 & 119 & 99 & \pm 12 \\
\hline Cyhalothrin & 85 & 105 & 97 & \pm 7 \\
\hline Cypermethrin & 81 & 103 & 95 & \pm 7 \\
\hline Cyproconazole & 77 & 103 & 86 & \pm 7 \\
\hline Cyprodinil & 78 & 114 & 89 & \pm 11 \\
\hline DCPA & 91 & 112 & 97 & \pm 7 \\
\hline$p, p^{\prime}-\mathrm{DDD}$ & 73 & 101 & 89 & \pm 9 \\
\hline$p, p^{\prime}-\mathrm{DDE}$ & 72 & 114 & 85 & \pm 12 \\
\hline$p, p^{\prime}-\mathrm{DDT}$ & 77 & 103 & 94 & \pm 10 \\
\hline Deltamethrin & 75 & 113 & 97 & \pm 11 \\
\hline Desulfinylfipronil & 82 & 104 & 96 & \pm 7 \\
\hline Diazinon & 91 & 110 & 99 & \pm 6 \\
\hline 3,4-Dichloroaniline $(3,4-\mathrm{DCA})^{* *}$ & 77 & 110 & 98 & \pm 9 \\
\hline 3,5-Dichloroaniline $(3,5$-DCA) & 72 & 102 & 89 & \pm 11 \\
\hline$N$-(3,4-Dichlorophenyl)- $N$ '-methylurea (DCPMU)** & 76 & 106 & 93 & \pm 10 \\
\hline 3,4-Dichlorophenylurea (DCPU)** & 72 & 101 & 89 & \pm 10 \\
\hline Difenoconazole & 78 & 103 & 93 & \pm 7 \\
\hline (E)-Dimethomorph & 78 & 106 & 95 & \pm 8 \\
\hline Dinotefuran $* *$ & 72 & 108 & 86 & \pm 12 \\
\hline Diuron** & 76 & 117 & 93 & \pm 12 \\
\hline Esfenvalerate & 74 & 118 & 99 & \pm 14 \\
\hline Ethalfluralin & 78 & 113 & 98 & \pm 13 \\
\hline Etofenprox & 85 & 103 & 91 & \pm 5 \\
\hline$S$-Ethyl dipropylthiocarbamate (EPTC) & 83 & 108 & 97 & \pm 10 \\
\hline Famoxadone & 78 & 110 & 93 & \pm 11 \\
\hline Fenarimol & 81 & 104 & 90 & \pm 7 \\
\hline Fenbuconazole & 78 & 107 & 97 & \pm 9 \\
\hline Fenhexamide & 83 & 103 & 92 & \pm 7 \\
\hline Fenpropathrin & 77 & 102 & 92 & \pm 8 \\
\hline Fipronil & 90 & 120 & 105 & \pm 12 \\
\hline Fipronil sulfide & 87 & 113 & 100 & \pm 8 \\
\hline Fipronil sulfone & 89 & 114 & 105 & \pm 9 \\
\hline Fluazinam & 70 & 80 & 75 & \pm 4 \\
\hline Fludioxinil & 82 & 103 & 90 & \pm 7 \\
\hline Fluoxastrobin & 72 & 113 & 93 & \pm 14 \\
\hline
\end{tabular}


Table 5. Minimum, maximum, and median recovery, and standard deviation of the recoveries, represented as a percentage for all compounds added to laboratory spiked water samples.-Continued

[Five spiked samples and five spiked replicate samples were analyzed by gas chromatography with mass spectrometry (GC/MS). Compounds noted with ** were analyzed in six spiked samples and six spiked replicate samples by liquid chromatography with tandem mass spectrometry (LC/MS/MS). Abbreviations: $\%$, percent; \pm , plus or minus]

\begin{tabular}{|c|c|c|c|c|}
\hline Compound & $\begin{array}{l}\text { Minimum recovery } \\
\quad \text { (in percent) }\end{array}$ & $\begin{array}{l}\text { Maximum recovery } \\
\text { (in percent) }\end{array}$ & $\begin{array}{l}\text { Median recovery } \\
\text { (in percent) }\end{array}$ & $\begin{array}{l}\text { Standard deviation } \\
\text { (in percent) }\end{array}$ \\
\hline Flusilazole & 70 & 105 & 84 & \pm 11 \\
\hline Flutriafol & 88 & 118 & 101 & \pm 8 \\
\hline Hexazinone & 79 & 112 & 94 & \pm 11 \\
\hline Imazalil & 80 & 117 & 99 & \pm 13 \\
\hline Kresoxim-methyl & 79 & 103 & 86 & \pm 8 \\
\hline Malathion & 87 & 110 & 102 & \pm 8 \\
\hline Metconazole & 85 & 116 & 99 & \pm 9 \\
\hline Methidathion & 88 & 114 & 104 & \pm 9 \\
\hline Methoprene & 81 & 106 & 94 & \pm 9 \\
\hline Methylparathion & 93 & 113 & 104 & \pm 7 \\
\hline Napropamide & 90 & 107 & 102 & \pm 5 \\
\hline Oxyfluorfen & 92 & 119 & 105 & \pm 9 \\
\hline Pebulate & 81 & 100 & 92 & \pm 7 \\
\hline Pendimethalin & 83 & 130 & 106 & \pm 13 \\
\hline Pentachloroanisole (PCA) & 70 & 97 & 81 & \pm 9 \\
\hline Pentachloronitrobenzene (PCNB) & 76 & 93 & 83 & \pm 5 \\
\hline Permethrin & 85 & 107 & 97 & \pm 6 \\
\hline Phenothrin & 72 & 105 & 86 & \pm 10 \\
\hline Phosmet & 92 & 120 & 104 & \pm 10 \\
\hline Piperonyl butoxide & 96 & 112 & 105 & \pm 5 \\
\hline Prometon & 88 & 120 & 104 & \pm 8 \\
\hline Tebuconazole & 80 & 121 & 101 & \pm 14 \\
\hline Tefluthrin & 77 & 104 & 87 & \pm 9 \\
\hline Tetraconazole & 74 & 110 & 86 & \pm 9 \\
\hline Tetramethrin & 76 & 103 & 90 & \pm 9 \\
\hline Thiacloprid** & 72 & 105 & 82 & \pm 10 \\
\hline Thiamethoxam** & 70 & 113 & 86 & \pm 13 \\
\hline Thiobencarb & 93 & 105 & 99 & \pm 4 \\
\hline Triadimefon & 78 & 101 & 90 & \pm 8 \\
\hline Triadimenol & 86 & 114 & 101 & \pm 8 \\
\hline Trifloxystrobin & 74 & 106 & 89 & \pm 10 \\
\hline Triflumizole & 71 & 116 & 91 & \pm 14 \\
\hline Trifluralin & 76 & 96 & 86 & \pm 7 \\
\hline Triticonazole & 78 & 107 & 96 & \pm 9 \\
\hline Zoxamide & 76 & 110 & 95 & \pm 13 \\
\hline
\end{tabular}


Table 6. Pesticide detection frequencies and maximum concentrations measured in environmental water samples collected from the Sacramento and San Joaquin Rivers.

[Abbreviations: ng/L, nanograms per liter; \%, percent; —, not detected]

\begin{tabular}{|c|c|c|c|c|c|}
\hline \multirow[b]{2}{*}{ Compound } & \multirow[b]{2}{*}{$\begin{array}{c}\text { Pesticide } \\
\text { type }\end{array}$} & \multicolumn{2}{|c|}{ Sacramento River at Freeport } & \multicolumn{2}{|c|}{ San Joaquin River near Vernalis } \\
\hline & & $\begin{array}{c}\text { Detection } \\
\text { frequency } \\
\text { (in percent) }\end{array}$ & $\begin{array}{c}\text { Maximum } \\
\text { concentration } \\
\text { (ng/L) }\end{array}$ & $\begin{array}{l}\text { Detection } \\
\text { frequency } \\
\text { (in percent) }\end{array}$ & $\begin{array}{c}\text { Maximum } \\
\text { concentration } \\
\text { (ng/L) }\end{array}$ \\
\hline Atrazine & Herbicide & - & - & $4 \%$ & 39.1 \\
\hline Azoxystrobin & Fungicide & $88 \%$ & 368 & $75 \%$ & 39.8 \\
\hline Boscalid & Fungicide & $15 \%$ & 82.9 & $96 \%$ & 112 \\
\hline Chlorothalonil & Fungicide & $6 \%$ & 3.0 & - & - \\
\hline Chlorpyrifos & Insecticide & - & - & $8 \%$ & 14.7 \\
\hline Clomazone & Herbicide & $35 \%$ & 670 & - & - \\
\hline Clothianidin & Insecticide & - & - & $13 \%$ & 1.9 \\
\hline Cyprodinil & Fungicide & $3 \%$ & 6.6 & $4 \%$ & 9.2 \\
\hline 3,4-Dichlorophenylurea (DCPU) & Degradate & - & - & $13 \%$ & 10.8 \\
\hline Difenoconazole & Fungicide & - & - & $4 \%$ & 18.2 \\
\hline Diuron & Herbicide & $56 \%$ & 42.6 & $96 \%$ & 695 \\
\hline$S$-Ethyl dipropylthiocarbamate (EPTC) & Herbicide & - & - & $4 \%$ & 49.2 \\
\hline Famoxadone & Fungicide & $12 \%$ & 21.6 & - & - \\
\hline Fipronil & Insecticide & $15 \%$ & 20.4 & - & - \\
\hline Hexazinone & Herbicide & $100 \%$ & 130 & $100 \%$ & 984 \\
\hline Imazalil & Fungicide & $15 \%$ & 30.7 & $4 \%$ & 53.4 \\
\hline Imidacloprid & Insecticide & $6 \%$ & 1.7 & $8 \%$ & 2.3 \\
\hline Iprodione & Fungicide & - & - & $4 \%$ & 21.5 \\
\hline Prometryn & Herbicide & - & - & $17 \%$ & 155 \\
\hline Propanil & Herbicide & $12 \%$ & 110 & - & - \\
\hline Propiconazole & Fungicide & $29 \%$ & 28.4 & $17 \%$ & 15.3 \\
\hline Pyraclostrobin & Fungicide & - & - & $8 \%$ & 20.2 \\
\hline Simazine & Herbicide & $53 \%$ & 87.7 & $83 \%$ & 524 \\
\hline Thiobencarb & Herbicide & $12 \%$ & 81.9 & - & - \\
\hline Trifluralin & Herbicide & $3 \%$ & 2.3 & - & - \\
\hline
\end{tabular}




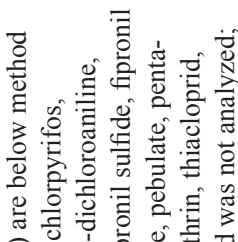
○ी

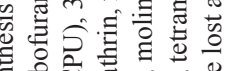

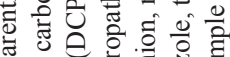

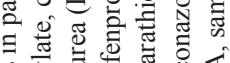

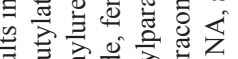

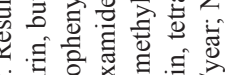

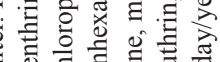

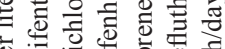
就过 जี

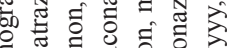
छี.

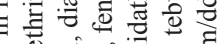
氙总司

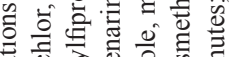

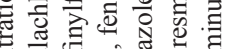

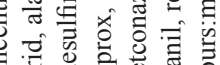

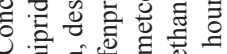

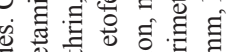
ᄋ ठ

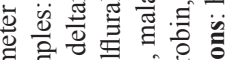

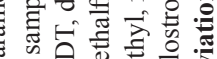
2.

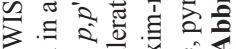
乙 ర્త

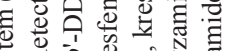

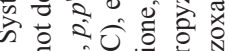

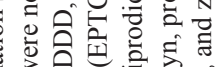

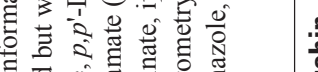

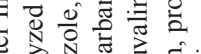

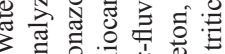
ఫٓ

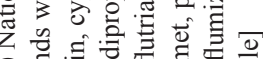

흠 宗

을 言 흥 즌

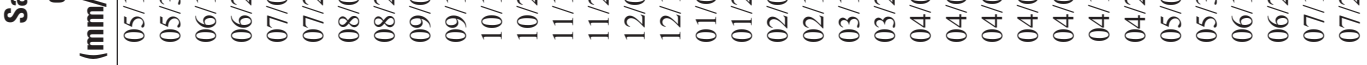

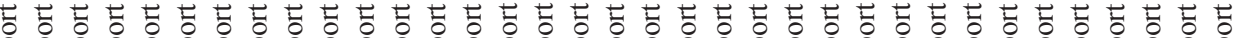
o. o \& 0

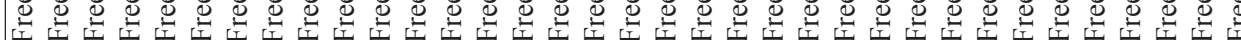

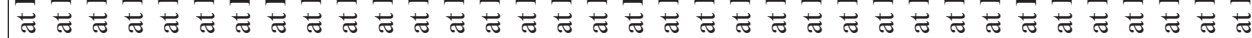

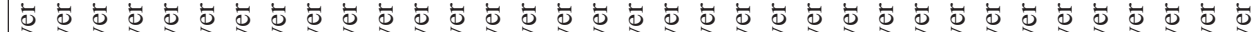

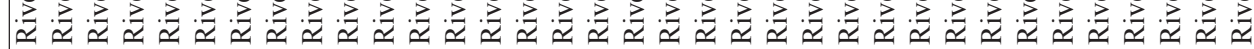

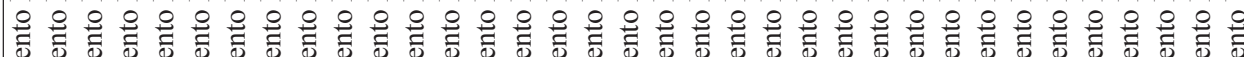




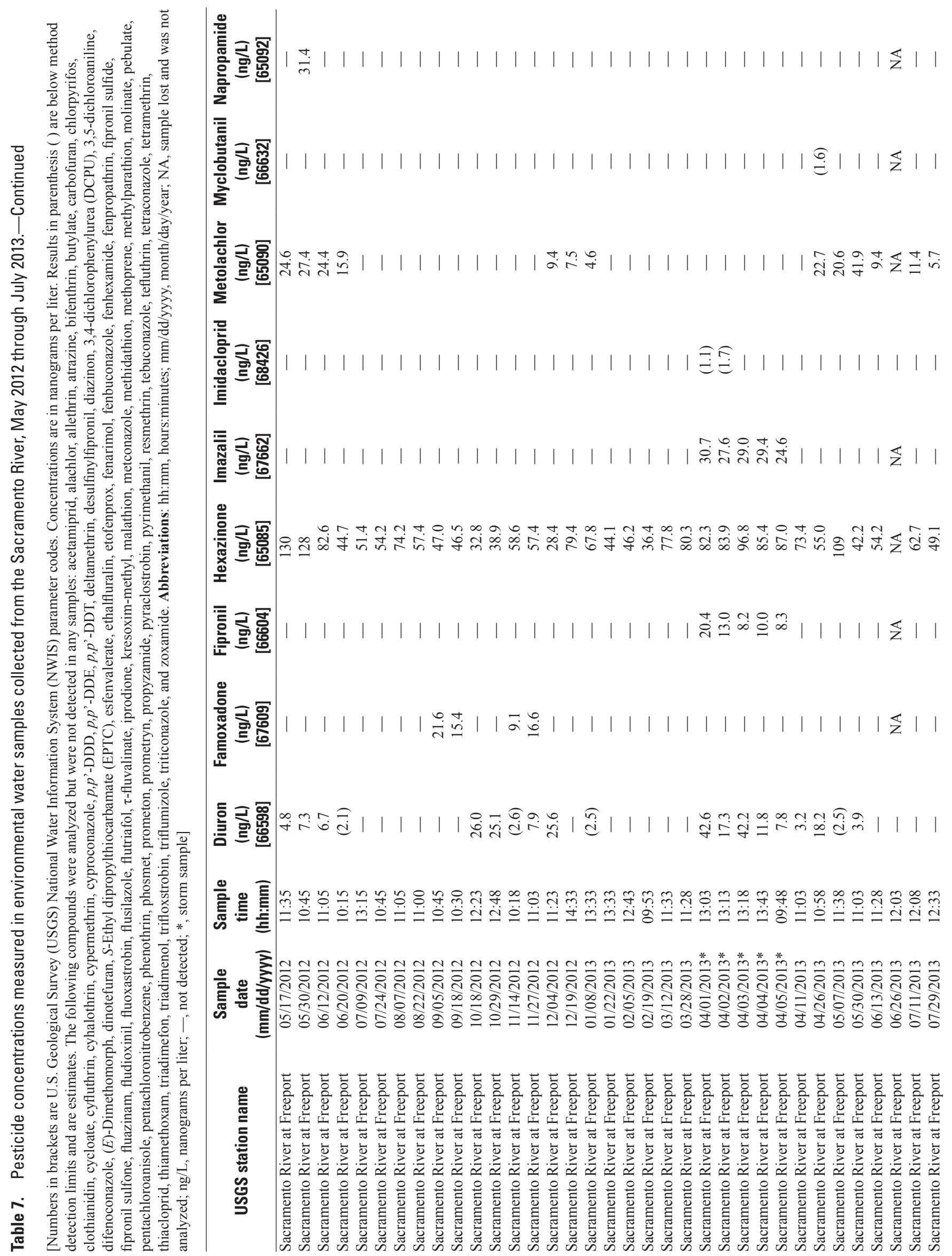


Results 17

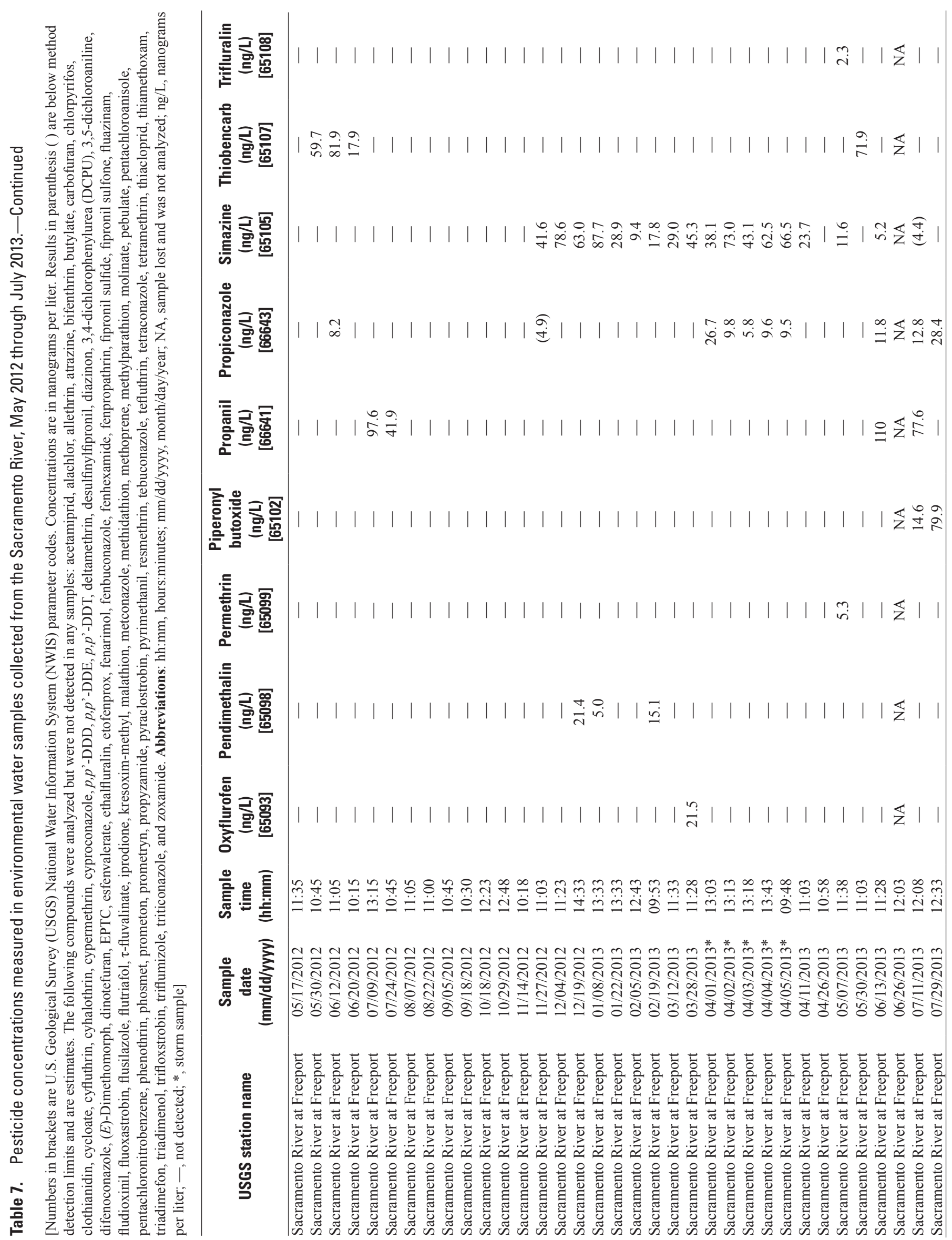




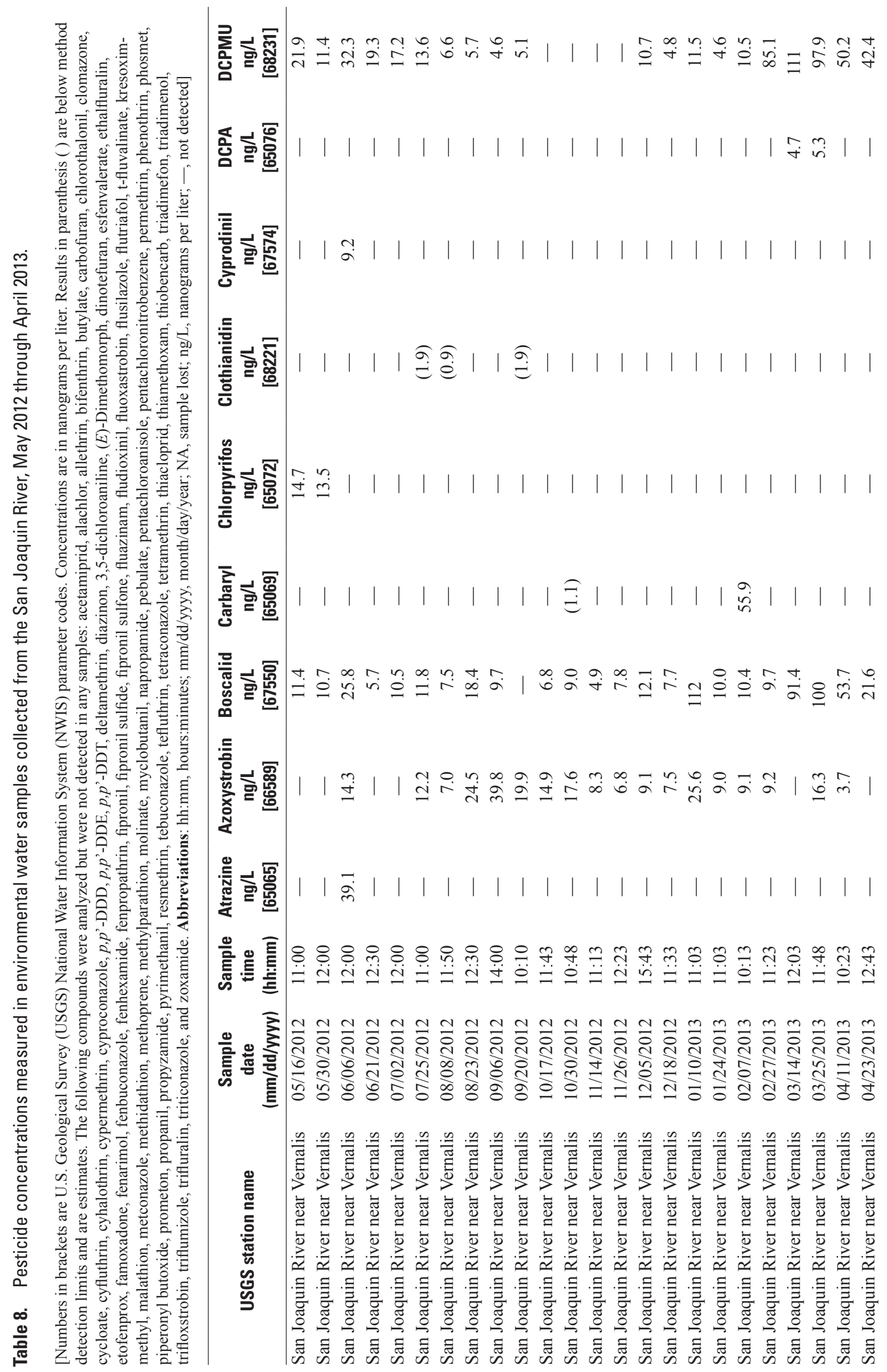




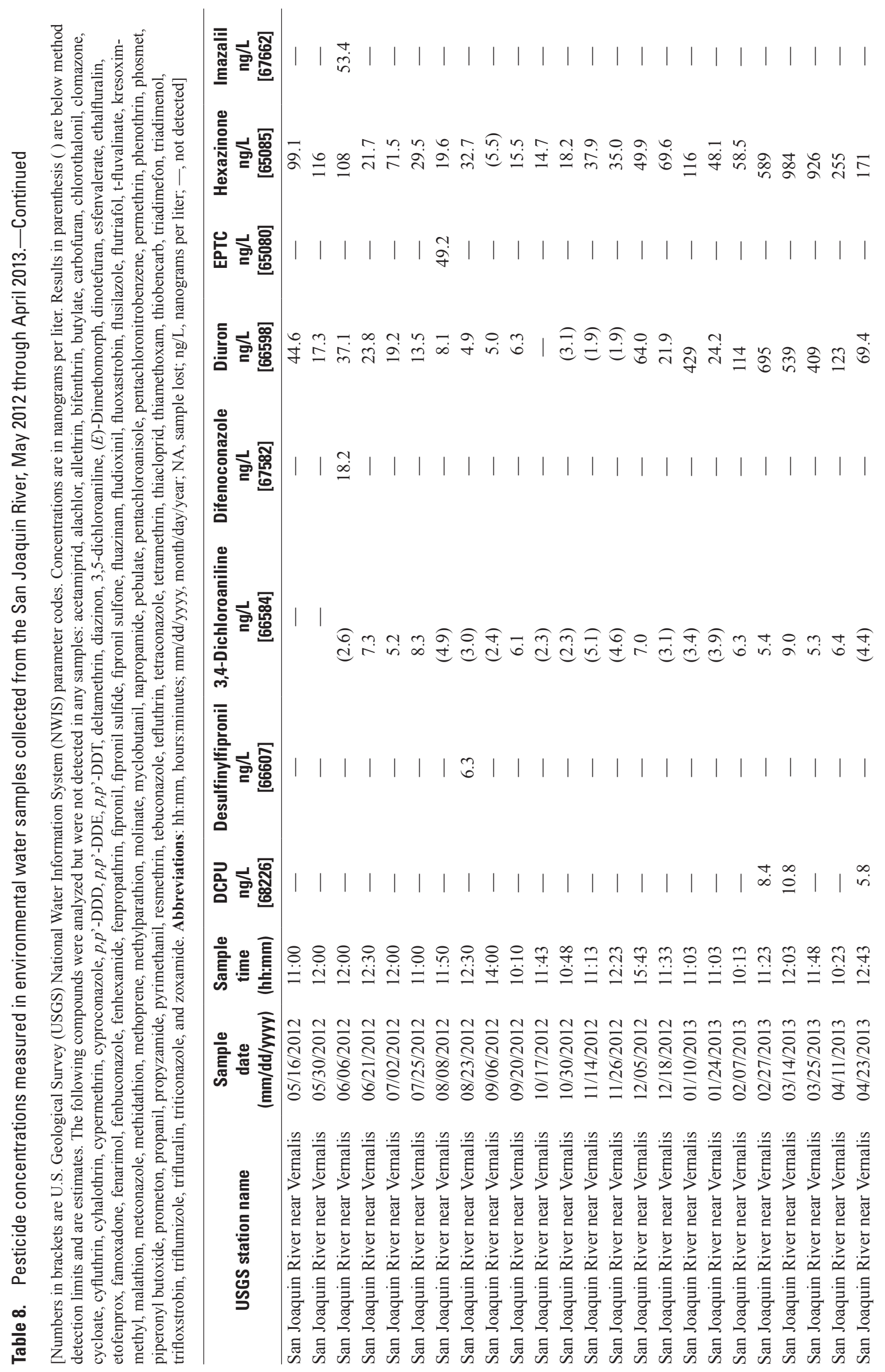




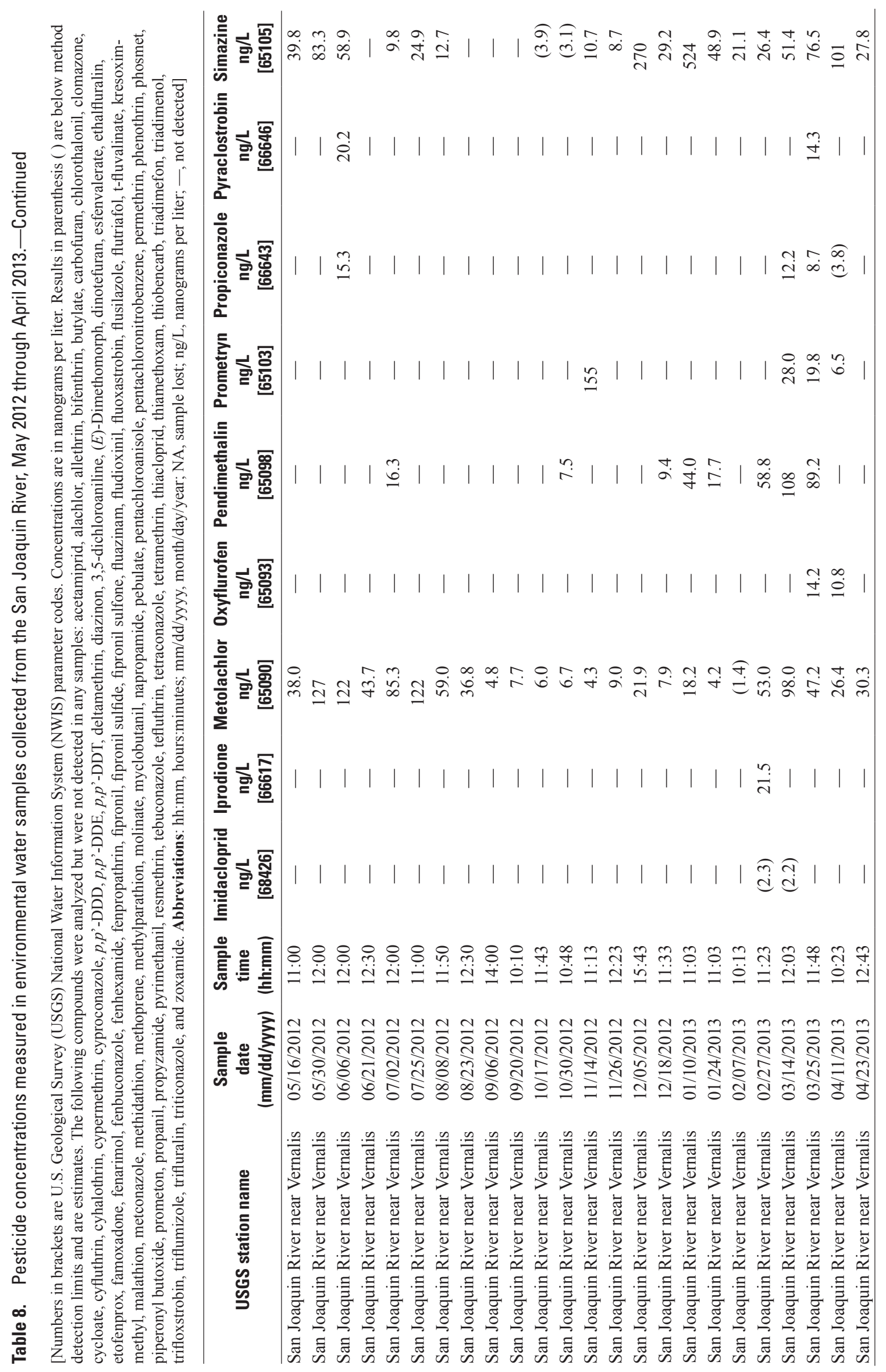


Table 9. Water-quality parameter data measured in water samples collected from the Sacramento and San Joaquin Rivers, May 2012 through July 2013.

[Numbers in brackets are U.S. Geological Survey (USGS) National Water Information System (NWIS) parameter codes. Abbreviations: hh:mm, hours:minutes; mg/L, miligrams/liter; mm/dd/yyyy, month/day/year; —, data not collected; ${ }^{\circ} \mathrm{C}$, degrees Celsius; $\mu \mathrm{S} / \mathrm{cm}$, microsiemens per centimeter]

\begin{tabular}{|c|c|c|c|c|c|c|}
\hline USGS station name & $\begin{array}{c}\text { Sample } \\
\text { date } \\
\text { (mm/dd/yyyy) }\end{array}$ & $\begin{array}{c}\text { Sample } \\
\text { time } \\
\text { (hh:mm) }\end{array}$ & $\begin{array}{c}\text { Water } \\
\text { temperature } \\
\left({ }^{\circ} \mathrm{C}\right) \\
{[00010]}\end{array}$ & $\begin{array}{c}\text { Specific } \\
\text { conductance } \\
(\mu \mathrm{S} / \mathrm{cm}) \\
{[00095]}\end{array}$ & $\begin{array}{c}\text { Dissolved } \\
\text { oxygen } \\
\text { (mg/L) } \\
{[00300]}\end{array}$ & $\begin{array}{c}\mathrm{pH} \\
{[00400]}\end{array}$ \\
\hline Sacramento River at Freeport & $05 / 30 / 2012$ & $10: 45$ & 19.6 & 139 & 9.1 & 7.7 \\
\hline Sacramento River at Freeport & $06 / 12 / 2012$ & $11: 05$ & 19.9 & 133 & 9.3 & 7.6 \\
\hline Sacramento River at Freeport & $07 / 24 / 2012$ & $10: 45$ & 20.9 & 119 & 8.8 & 7.5 \\
\hline Sacramento River at Freeport & 08/07/2012 & $11: 05$ & 20.2 & 118 & - & 7.7 \\
\hline Sacramento River at Freeport & $08 / 22 / 2012$ & $11: 00$ & 21.2 & - & 8.7 & 7.8 \\
\hline Sacramento River at Freeport & $09 / 05 / 2012$ & $10: 45$ & 20.0 & - & 8.9 & 7.8 \\
\hline Sacramento River at Freeport & $09 / 18 / 2012$ & $10: 30$ & 19.2 & - & 8.9 & 7.8 \\
\hline Sacramento River at Freeport & $10 / 18 / 2012$ & $12: 23$ & 18.6 & 128 & 9.2 & 7.7 \\
\hline Sacramento River at Freeport & $12 / 04 / 2012$ & $11: 23$ & 12.9 & 102 & 8.3 & 7.0 \\
\hline Sacramento River at Freeport & $12 / 19 / 2012$ & $14: 33$ & 9.2 & 168 & 10.3 & 7.7 \\
\hline Sacramento River at Freeport & $01 / 08 / 2013$ & $13: 33$ & 7.9 & 178 & 12.6 & 7.6 \\
\hline Sacramento River at Freeport & $01 / 22 / 2013$ & $13: 33$ & 7.7 & 172 & - & 7.9 \\
\hline Sacramento River at Freeport & $02 / 05 / 2013$ & $12: 43$ & 9.9 & 177 & 10.8 & 7.8 \\
\hline Sacramento River at Freeport & $02 / 19 / 2013$ & $09: 53$ & 10.6 & 151 & 10.8 & 7.5 \\
\hline Sacramento River at Freeport & $03 / 12 / 2013$ & $11: 33$ & 12.9 & 152 & 8.6 & 8.0 \\
\hline Sacramento River at Freeport & $03 / 28 / 2013$ & $11: 28$ & 14.8 & 135 & 10.1 & 7.7 \\
\hline Sacramento River at Freeport & $04 / 01 / 2013$ & $13: 03$ & 16.8 & 129 & 10.9 & 8.1 \\
\hline Sacramento River at Freeport & $04 / 02 / 2013$ & $13: 13$ & 16.7 & 143 & 11.2 & 8.2 \\
\hline Sacramento River at Freeport & $04 / 03 / 2013$ & $13: 18$ & 16.7 & 134 & 11.1 & 8.2 \\
\hline Sacramento River at Freeport & $07 / 11 / 2013$ & $12: 08$ & 21.5 & 126 & 8.0 & 7.9 \\
\hline Sacramento River at Freeport & $07 / 29 / 2013$ & $12: 33$ & 21.3 & 139 & 7.7 & 7.5 \\
\hline San Joaquin River near Vernalis & $05 / 16 / 2012$ & $11: 00$ & 17.9 & 264 & 9.2 & 7.7 \\
\hline San Joaquin River near Vernalis & $05 / 30 / 2012$ & $12: 00$ & 19.5 & 317 & 9.9 & 8.1 \\
\hline San Joaquin River near Vernalis & $06 / 06 / 2012$ & $12: 00$ & 19.1 & 525 & 10.4 & 8.3 \\
\hline San Joaquin River near Vernalis & $06 / 21 / 2012$ & $12: 30$ & 22.1 & 397 & 11.0 & 8.8 \\
\hline San Joaquin River near Vernalis & $07 / 02 / 2012$ & $12: 00$ & 23.5 & - & - & - \\
\hline San Joaquin River near Vernalis & $07 / 25 / 2012$ & $11: 00$ & 24.6 & 514 & 11.2 & 8.7 \\
\hline San Joaquin River near Vernalis & 08/08/2012 & $11: 50$ & 24.6 & 581 & 9.9 & 8.6 \\
\hline San Joaquin River near Vernalis & $08 / 23 / 2012$ & $12: 30$ & 25.0 & 629 & 9.2 & 8.5 \\
\hline San Joaquin River near Vernalis & $09 / 06 / 2012$ & $14: 00$ & 23.0 & 640 & 8.9 & 8.1 \\
\hline San Joaquin River near Vernalis & $09 / 20 / 2012$ & $10: 10$ & 20.0 & - & - & 7.9 \\
\hline San Joaquin River near Vernalis & $10 / 17 / 2012$ & $11: 43$ & 17.3 & 402 & 9.5 & 7.8 \\
\hline San Joaquin River near Vernalis & $10 / 30 / 2012$ & $10: 48$ & 16.0 & - & - & - \\
\hline San Joaquin River near Vernalis & $11 / 14 / 2012$ & $11: 13$ & 12.0 & 712 & 10.3 & 7.9 \\
\hline San Joaquin River near Vernalis & $11 / 26 / 2012$ & $12: 23$ & 12.5 & 699 & - & 7.8 \\
\hline San Joaquin River near Vernalis & $12 / 05 / 2012$ & $15: 43$ & - & - & - & - \\
\hline
\end{tabular}


Table 9. Water-quality parameter data measured in water samples collected from the Sacramento and San Joaquin Rivers, May 2012 through July 2013.-Continued

[Numbers in brackets are U.S. Geological Survey (USGS) National Water Information System (NWIS) parameter codes. Abbreviations: hh:mm, hours:minutes; $\mathrm{mg} / \mathrm{L}$, miligrams/liter; $\mathrm{mm} / \mathrm{dd} / \mathrm{yyyy}$, month/day/year; —, data not collected; ${ }^{\circ} \mathrm{C}$, degrees Celsius; $\mu \mathrm{S} / \mathrm{cm}$, microsiemens per centimeter]

\begin{tabular}{|c|c|c|c|c|c|c|}
\hline USGS station name & $\begin{array}{c}\text { Sample } \\
\text { date } \\
\text { (mm/dd/yyyy) }\end{array}$ & $\begin{array}{l}\text { Sample } \\
\text { time } \\
\text { (hh:mm) }\end{array}$ & $\begin{array}{c}\text { Water } \\
\text { temperature } \\
\left({ }^{\circ} \mathrm{C}\right) \\
{[00010]}\end{array}$ & $\begin{array}{c}\text { Specific } \\
\text { conductance } \\
(\mu \mathrm{S} / \mathrm{cm}) \\
{[00095]}\end{array}$ & $\begin{array}{c}\text { Dissolved } \\
\text { oxygen } \\
\text { (mg/L) } \\
\text { [00300] }\end{array}$ & $\begin{array}{c}\mathrm{pH} \\
{[00400]}\end{array}$ \\
\hline San Joaquin River near Vernalis & $12 / 18 / 2012$ & $11: 33$ & 10.7 & 840 & 9.9 & 7.8 \\
\hline San Joaquin River near Vernalis & $01 / 10 / 2013$ & $11: 03$ & 8.2 & 652 & 12.9 & 7.7 \\
\hline San Joaquin River near Vernalis & $01 / 24 / 2013$ & $11: 03$ & 9.9 & 969 & 9.9 & 7.8 \\
\hline San Joaquin River near Vernalis & $03 / 14 / 2013$ & $12: 03$ & 17.1 & 822 & 9.8 & 8.2 \\
\hline San Joaquin River near Vernalis & $03 / 25 / 2013$ & $11: 48$ & 16.0 & 10 & 10.0 & 7.9 \\
\hline San Joaquin River near Vernalis & $04 / 11 / 2013$ & $10: 23$ & 19.3 & - & - & - \\
\hline San Joaquin River near Vernalis & $04 / 23 / 2013$ & $12: 43$ & 17.5 & 276 & 8.6 & 7.9 \\
\hline
\end{tabular}

\section{Sacramento River}

At least three pesticides or pesticide degradates were detected in every Sacramento River water sample analyzed by $\mathrm{GC} / \mathrm{MS}$ and LC/MS/MS. A total of 27 compounds were detected: 8 fungicides, 14 herbicides/degradates, 4 insecticides, and 1 synergist (fig. 3). The most frequently detected compounds were the herbicide hexazinone (100 percent of samples), followed by the degradate 3,4-dichloroaniline (97 percent), the fungicide azoxystrobin (88 percent), and the herbicides diuron (56 percent) and simazine (50 percent; table 6 and fig. 3). Insecticides were infrequently detected except during storm samples as described later in this section. The numbers of pesticides detected varied during the sampling period and tended to increase following rainfall events, as shown in figure 4, which depicts the numbers of pesticides detected in samples collected during the study and average daily rainfall calculated from data recorded at 19 measurement sites in the Central Valley (fig. 1) (California Irrigation Management Information System, 2013). The timing of pesticide detections corresponded to patterns of pesticide use in the upstream watershed as shown in figure 5 , which depicts concentrations of four pesticides applied primarily to rice (azoxystrobin, clomazone, propanil, and thiobencarb), along with 3,4-dichloroaniline, which is a degradate of propanil in samples collected in 2012; and application amounts of these pesticides to rice in 2012 (California Department of Pesticide Regualtion, 2014).

Samples were collected from the Sacramento River at Freeport for 5 consecutive days following a moderate rainfall event (greater than 0.5 inch per day) that occurred in the Sacramento urban area on March 31, 2013. A second similar storm took place on April 4, 2013, during the 5-day sampling period. Twelve pesticides and (or) degradates were detected during the storm sampling period, including five (carbaryl, DCPA, fipronil, imazalil, and imidacloprid) that were not detected in any other Sacramento River samples (table 7). The average number of compounds detected in storm samples was 11 , whereas the average number of compounds detected in non-storm samples during the study was 6 .

Pesticide concentrations in Sacramento River samples ranged from below the respective MDLs to $670 \mathrm{ng} / \mathrm{L}$ (clomazone). Maximum concentrations of the compounds detected were less than $100 \mathrm{ng} / \mathrm{L}$ with the exceptions of azoxystrobin, clomazone, 3,4-dichloroaniline, hexazinone, and propanil (table 6). Box plots of concentrations of the most frequently detected pesticides in Sacramento River samples are shown in figure 6 .

A number of pesticides had increased concentrations (compared to non-storm samples) or were only detected during the storm event sampled in April 2013. Concentrations of the fungicides imazalil and propiconazole; and the insecticides carbaryl, fipronil, and imidacloprid, which showed increased concentrations in response to the two episodes of rainfall that occurred during the storm-sampling period, are shown in figure 7. The insecticide fipronil was detected in two consecutive storm samples (April 1-2,2013) at concentrations above the aquatic-life benchmark for chronic toxicity to invertebrates of $11 \mathrm{ng} / \mathrm{L}$.

In addition, the pyrethroid insecticide permethrin was detected in one non-storm sample (May 7, 2013) at a concentration above the aquatic-life benchmark for chronic toxicity to invertebrates of $1.4 \mathrm{ng} / \mathrm{L}$ (U.S. Environmental Protection Agency, 2012). All other pesticides with established aquatic-life benchmarks were detected at concentrations below those benchmarks. 


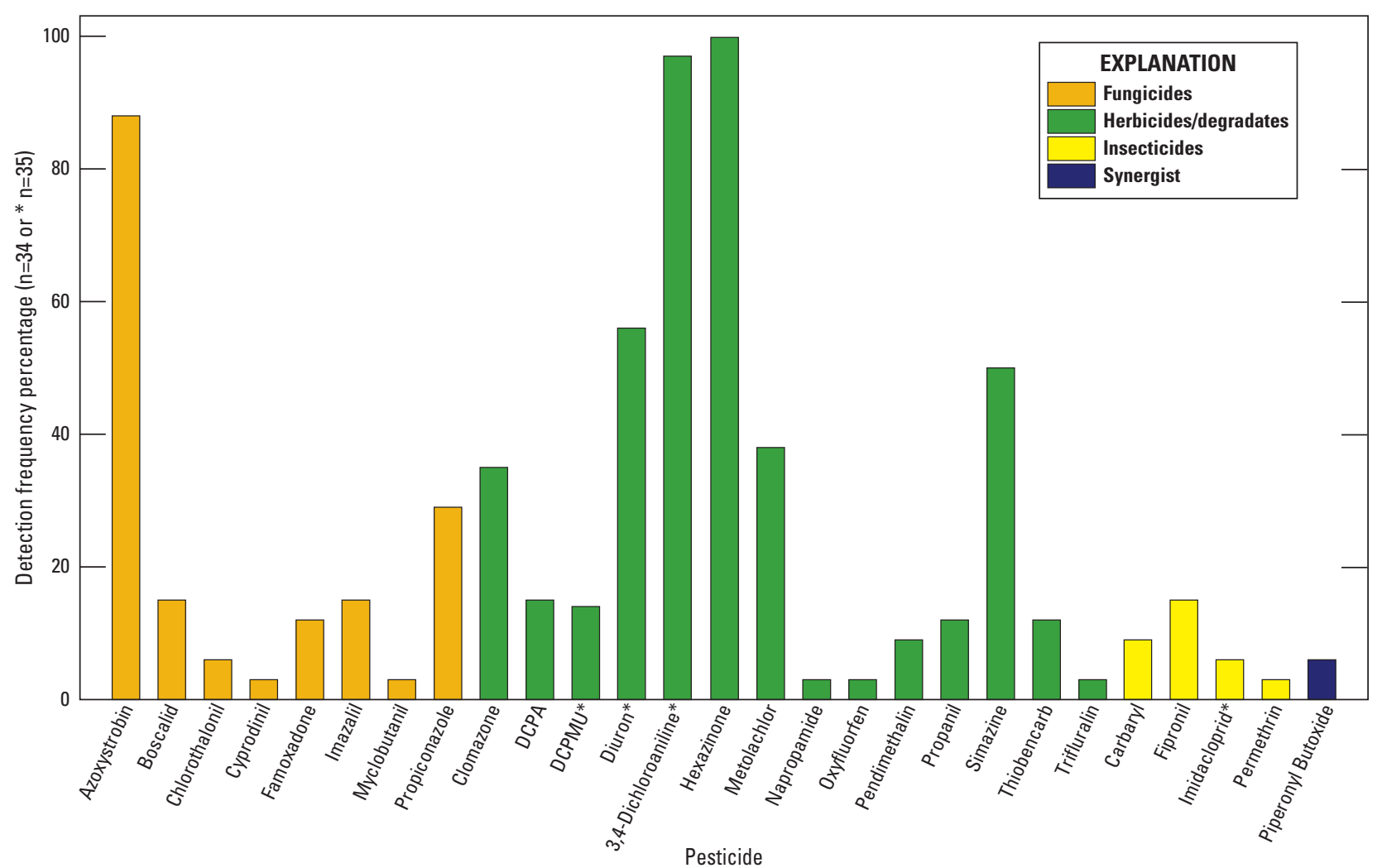

Figure 3. Pesticide detection frequencies at the Sacramento River at Freeport, May 2012 through July 2013.

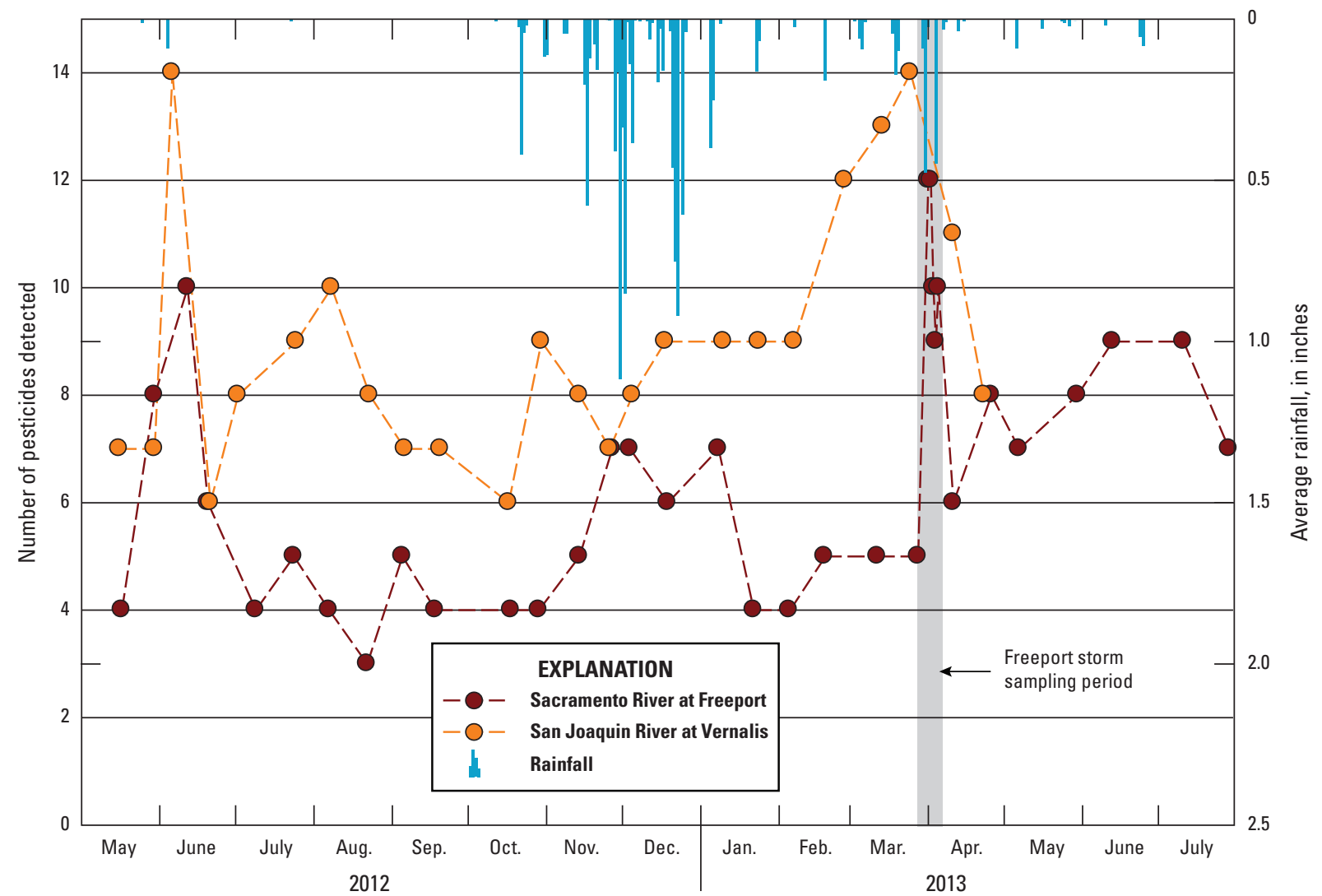

Figure 4. Numbers of pesticides detected in Sacramento River samples and San Joaquin River samples, and average daily rainfall in the Central Valley. 


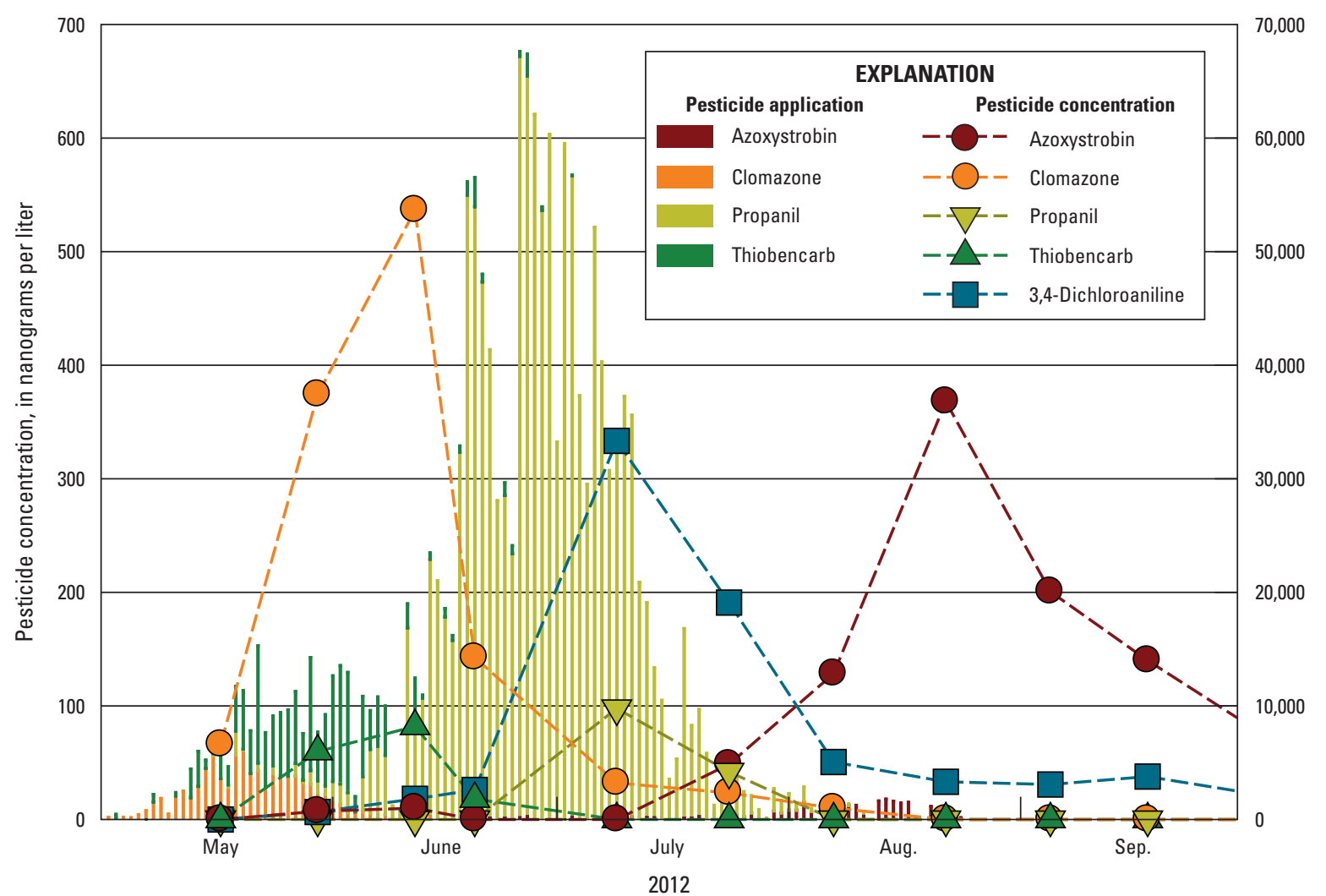

Figure 5. Concentrations of rice pesticides detected in Sacramento River samples, May 2012 through July 2013.

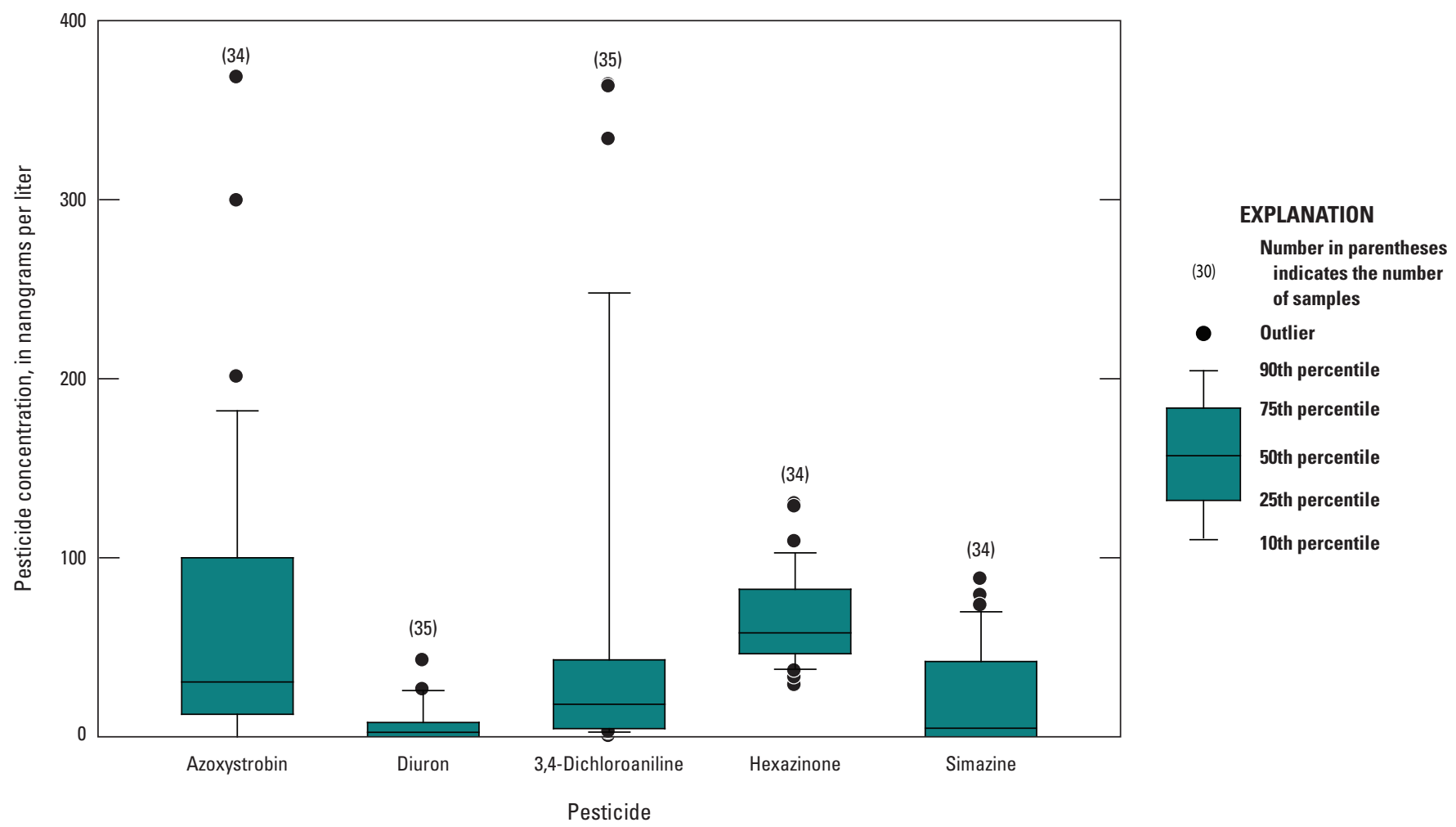

Figure 6. Concentrations of the most frequently detected pesticides in Sacramento River samples, May 2012 through July 2013. 


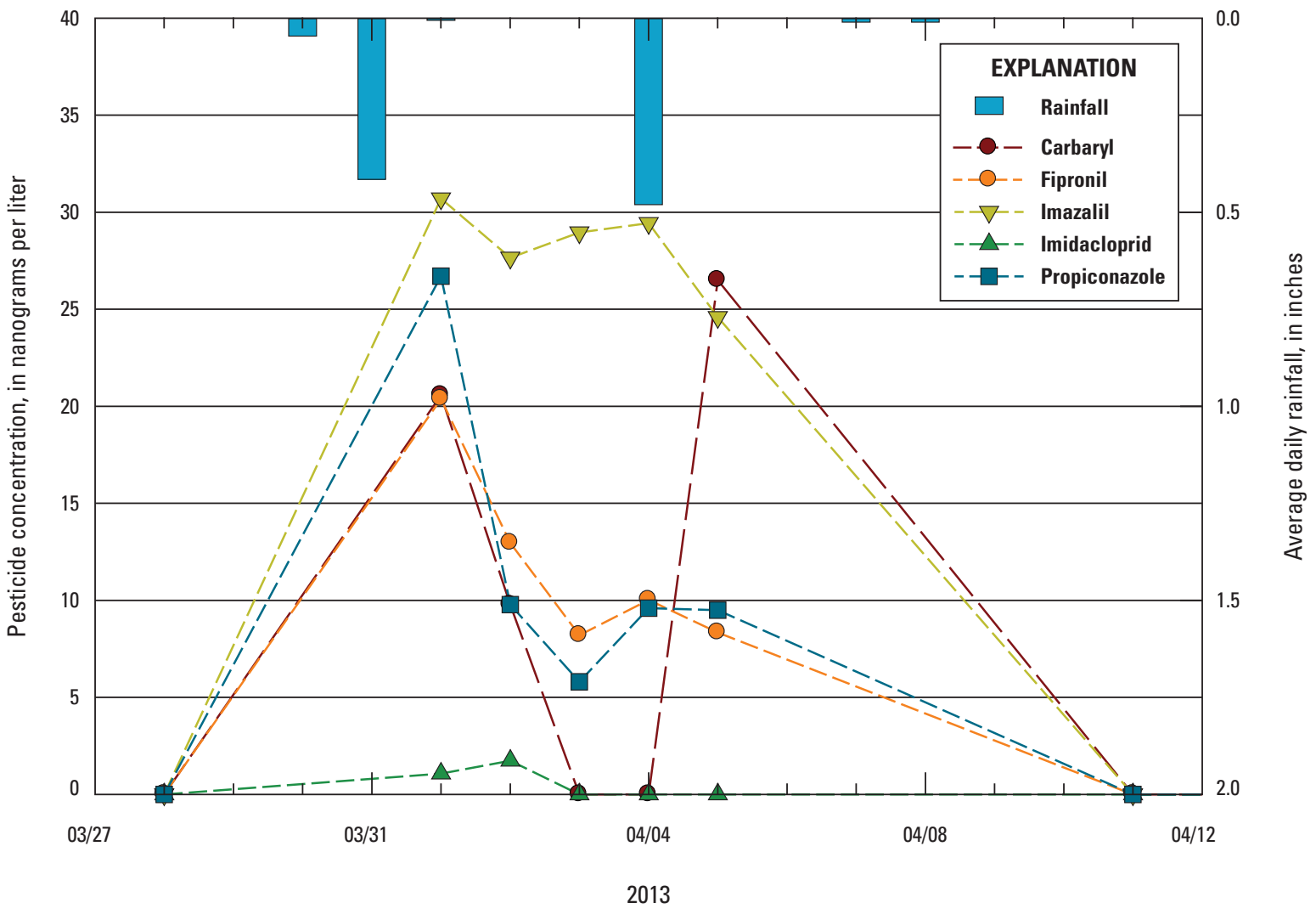

Figure 7. Concentrations of selected pesticides in Sacramento River storm samples collected April 1, 2013, through April 5, 2013, and average daily rainfall in the Sacramento Valley.

\section{San Joaquin River}

Surface-water samples collected from the San Joaquin River contained mixtures of $6-14$ pesticides and (or) degradates (fig. 4). A total of 27 compounds were detected: 9 fungicides, 13 herbicides/degradates, and 5 insecticides/ degradates (fig. 8). The most frequently detected compounds were the herbicides hexazinone and metolachlor (detected in 100 percent of samples), and diuron (96 percent); the fungicide boscalid (96 percent); the degradates 3,4-dicloroaniline (92 percent) and DCPMU (83 percent); the herbicide simazine (83 percent); and the fungicide azoxystrobin ( 75 percent; table 6, fig. 8). Insecticides were detected infrequently during the study. The numbers of pesticides detected varied during the sampling period (fig. 8) and did not consistently increase following rainfall events (fig. 4).
Maximum concentrations in San Joaquin River samples ranged from below the MDLs to as much as $984 \mathrm{ng} / \mathrm{L}$ (hexazinone; table 8). Maximum concentrations were less than $100 \mathrm{ng} / \mathrm{L}$, with the exception of eight pesticides (boscalid, DCPMU, diuron, hexazinone, metolachlor, pendimethalin, prometryn, and simazine; table 6). Box plots showing the range in concentrations of the most frequently detected pesticides are shown in figure 9. Pesticide concentrations varied during the study, likely in response to applications in the watershed, and with the exception of the herbicide simazine, concentrations did not consistently increase following rainfall events. Measured concentrations of pesticides with established aquatic-life benchmarks were all below those benchmarks (U.S. Environmental Protection Agency, 2012). 


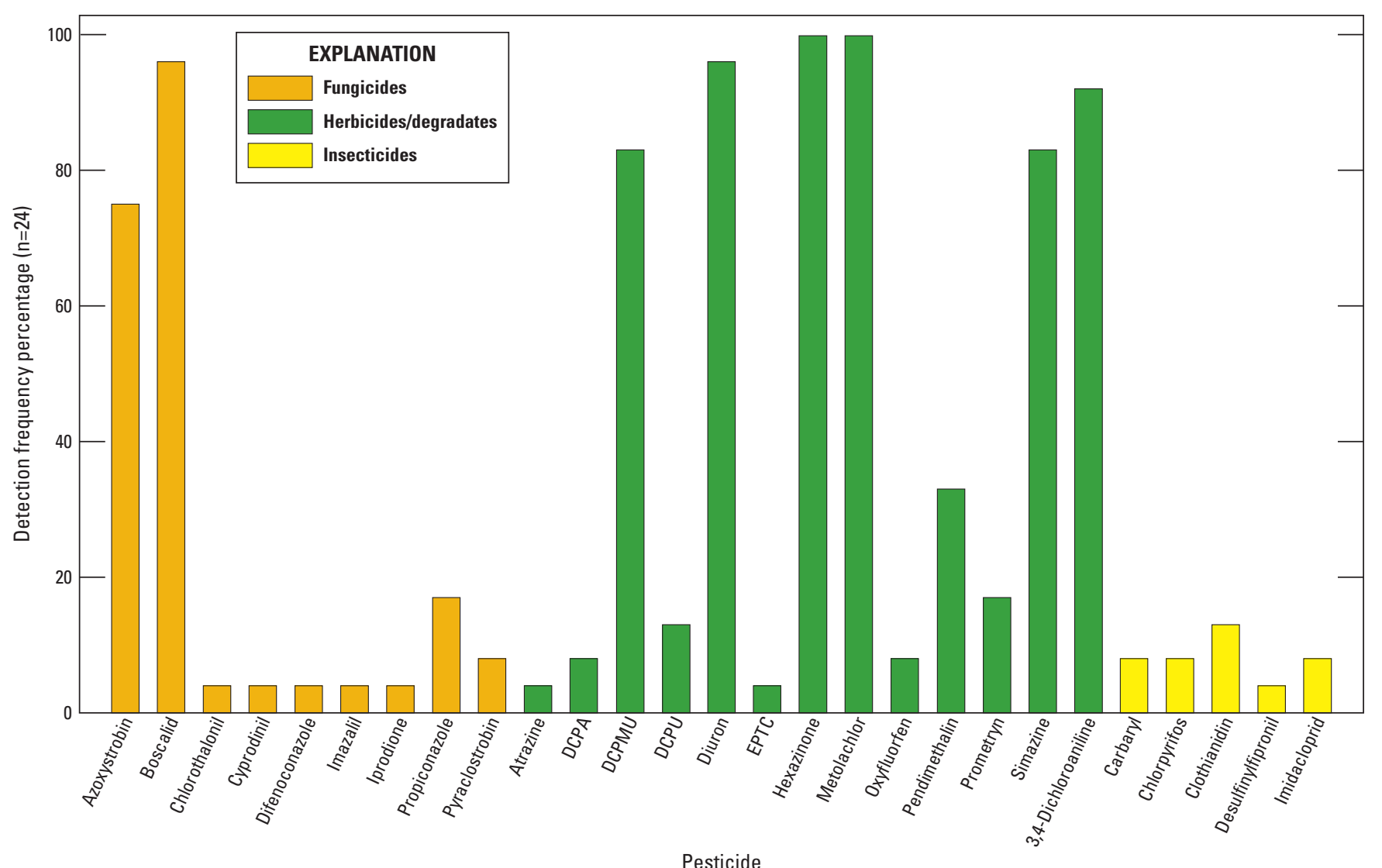

Figure 8. Pesticide detection frequencies at the San Joaquin River near Vernalis, May 2012 through April 2013.

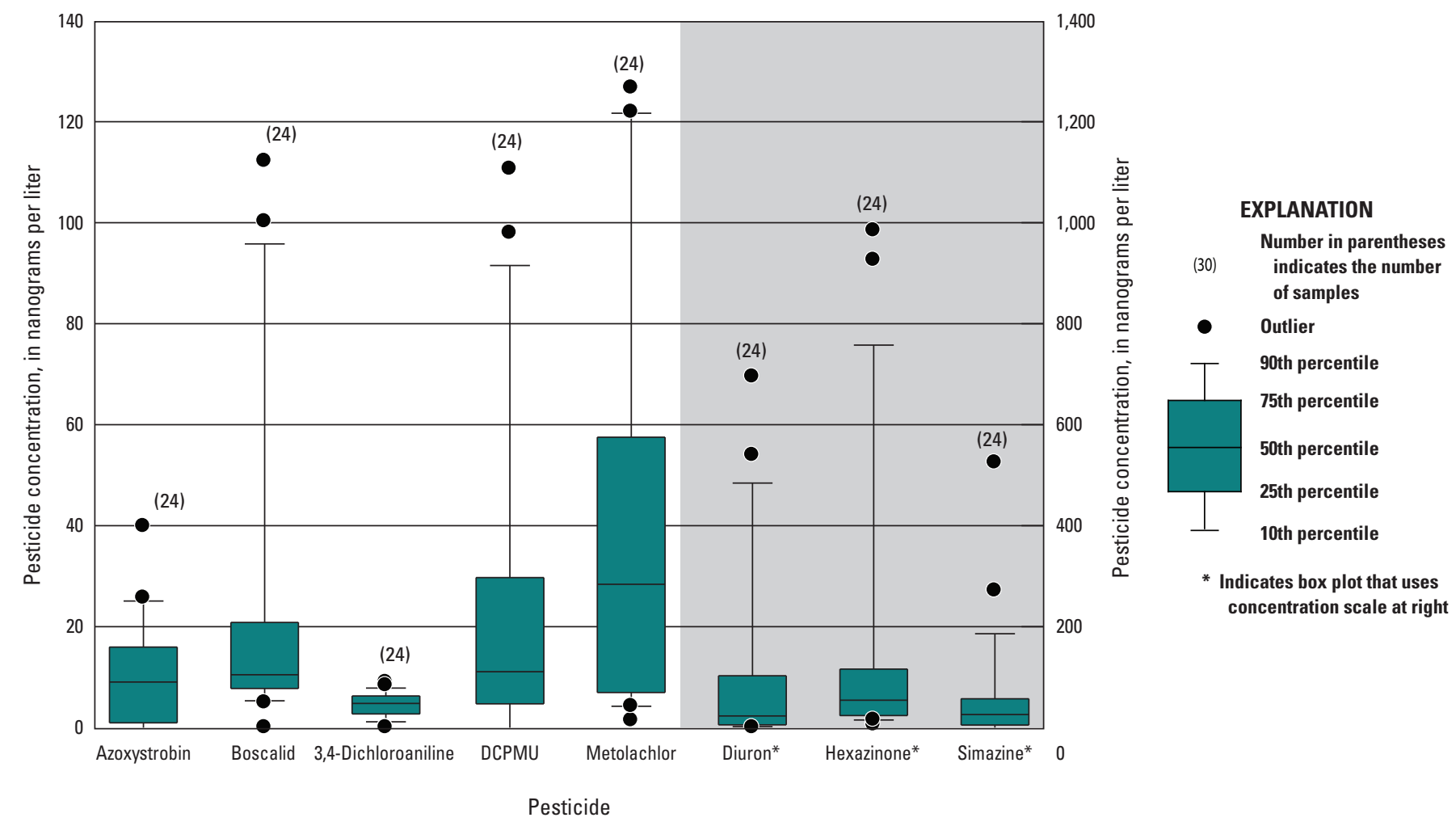

Figure 9. Concentrations of the most frequently detected pesticides in San Joaquin River samples, May 2012 through April 2013. 


\section{Summary}

Concentrations of dissolved pesticides and pesticide degradates were measured twice per month from May 2012 through July 2013, and May 2012 through April 2013 at the Sacramento River at Freeport and the San Joaquin River near Vernalis, respectively. Hydrologic conditions during the sampling period were characterized by below-normal flows for the Sacramento River during most of the sampling period, while San Joaquin River flows were below normal throughout the period. Rainfall events of greater than 1 inch in 24 hours were rare in the Sacramento and San Joaquin Valley floor regions throughout the study period.

A total of 37 pesticides and degradates were detected during the study including 11 fungicides, 18 herbicides/ degradates, 7 insecticides/degradates, and 1 synergist. The fungicide azoxystrobin; herbicides diuron, hexazinone metolachlor, and simazine; and the herbicide degradate 3,4-dichloroaniline were frequently detected in Sacramento and San Joaquin River samples. The fungicide boscalid, herbicide metolachlor, and herbicide degradate DCPMU were also frequently detected in San Joaquin River samples. All samples contained mixtures of multiple pesticides. Nonstorm Sacramento River samples contained an average of 6 pesticides, and San Joaquin River samples contained an average of 9 pesticides, while storm samples collected from the Sacramento River contained an average of 11 pesticides. The number of pesticides in Sacramento River samples tended to increase following rainfall events, but this was generally not the case for pesticides detected in San Joaquin River samples. Insecticides were infrequently detected during the study except in storm-samples from the Sacramento River.

Maximum pesticide concentrations measured during the study ranged from below the respective method detection limits to $984 \mathrm{ng} / \mathrm{L}$ (hexazinone). In general the most frequently detected pesticides were measured at higher concentrations than less frequently detected pesticides. Pesticides detected at the highest concentrations in Sacramento River samples were, with the exception of hexazinone, primarily associated with rice agriculture. For those compounds frequently detected in both Sacramento and San Joaquin River samples (azoxystrobin, 3,4-dichloroaniline, diuron, hexazinone, metolachlor, and simazine), maximum concentrations were higher in San Joaquin River samples with the exceptions of azoxystrobin and 3,4-dichloroaniline. The insecticide fipronil was detected in two consecutive Sacramento River stormsamples at concentrations above the aquatic-life benchmark for chronic toxicity to invertebrates of $11 \mathrm{ng} / \mathrm{L}$, and the pyrethroid insecticide permethrin was detected above its aquatic-life benchmark for chronic toxicity to invertebrates of $1.4 \mathrm{ng} / \mathrm{L}$ in one Sacramento River non-storm sample (U.S. Environmental Protection Agency, 2012). In San Joaquin River samples, concentrations of pesticides with established aquatic-life benchmarks were all below those benchmarks.

\section{References Cited}

California Department of Pesticide Regulation, 2014, Pesticide use data for 2012: Sacramento, California Department of Pesticide Regulation, accessed April 9, 2014, at http://www. cdpr.ca.gov/docs/pur/purmain.htm.

California Department of Water Resources, 1993, Sacramento San Joaquin Delta Atlas, California: Department of Water Resources, $121 \mathrm{p}$.

California Department of Water Resources, 2013a, Management of the California State Water Project, Bulletin 132-10, accessed August 12, 2013, at http://www.water. ca.gov/swpao/docs/bulletins/bulletin132/Bulletin132-10. pdf.]

California Department of Water Resources, 2013b, Contaminants in Bay Delta conservation plan, public draft, Sacramento, Calif., ICF International, appendix 5.D.

California Department of Water Resources, 2013c, Chronological reconstructed Sacramento and San Joaquin Valley water year hydrologic classification indices: accessed August 12, 2013, at http://cdec.water.ca.gov/cgi-progs/ iodir/wsihist.

California Irrigation Management Information System, 2013, Rainfall data for stations (Bryte, Colusa, Davis, Dixon, Durham, Esparto, Fair Oaks, Gerber, Hastings Tract East, Lodi West, Manteca, Merced, Modesto, Oakdale, Patterson, Tracy, Twitchell Island, Verona, and Winters) in the Sacramento and San Joaquin Valleys: accessed July 30, 2013, at http://wwwcimis.water.ca.gov

Dileanis, P.D., Bennett, K.P., and Domagalski, J.L., 2002, Occurrence and transport of diazinon in the Sacramento River, California, and selected tributaries, during three winter storms, January-February 2000: U.S. Geological Survey Water-Resources Investigations Report 02-4101, $71 \mathrm{p}$.

Dileanis, P.D., Brown, D.L., Knifong, D.L., and Saleh, D., 2003, Occurrence and transport of diazinon and chlorpyrifos in the Sacramento River and selected tributaries, California, during two winter storms, January-February 2001: U.S. Geological Survey Water-Resources Investigations Report 03-4111, 75 p.

Domagalski, J.L., Knifong, D.L., MacCoy, D.E., Dileanis, P.D., Dawson, B.J., and Majewski, M.S., 1998, Water quality assessment of the Sacramento River Basin, California - environmental setting and study design: U.S. Geological Survey Water-Resources Investigations Report 97-4254, $31 \mathrm{p}$.

Federal Interagency Sedimentation Project, 2000, Operating instructions for the US D-95 depth-integrating collapsible bag suspended-sediment sampler: accessed February 28, 2014, at http://water.usgs.gov/fisp/docs/Instructions_US_D95_000608.pdf. 
Federal Interagency Sedimentation Project, 2002, Operating instructions for the US D-96 depth-integrating collapsible bag suspended-sediment sampler: accessed February 28, 2014, at http://water.usgs.gov/fisp/docs/Instructions_US_D96_Instructions_020709.pdf.

Gilliom, R.J., Alley, W.M., and Gurtz, M.E., 1995, Design of the national water-quality assessment program-Occurrence and distribution of water-quality conditions: U.S. Geological Survey Circular 1112, 33 p.

Hladik, M.L., and Calhoun, D.L., 2012, Analysis of the herbicide diuron, three diuron degradates, and six neonicotinoid insecticides in water-Method details and application to two Georgia streams: U.S. Geological Survey Scientific Investigations Report 2012-5206, 10 p.

Hladik, M.L., Smalling, K.L., and Kuivila, K.M., 2008, A multi-residue method for the analysis of pesticides and pesticide degradates in water using Oasis HLB solid phase extraction and gas chromatography-ion trap mass spectrometry: Bulletin of Environmental Contamination and Toxicology, v. 80, p. 139-144.

Hladik, M.L., Smalling, K.L., and Kuivila, K.M., 2009, Methods of analysis: Determination of pyrethroid insecticides in water and sediment using gas chromatography/mass spectrometry: U.S. Geological Survey Techniques and Methods book 5, chap. C2, 18 p.

Kratzer, C.R., Zamora, C., and Knifong, D.L., 2002, Diazinon and chlorpyrifos loads in the San Joaquin River Basin, California, January and February 2000: U.S. Geological Survey Water-Resources Investigations Report 02-4103, $38 \mathrm{p}$.

Orlando, J.L., 2013, A compilation of U.S. Geological Survey pesticide concentration data for water and sediment in the Sacramento-San Joaquin Delta region-1990-2010: U.S. Geological Survey Data Series 756, 46 p.

Orlando, J.L., and Kuivila, K.M., 2004, Changes in rice pesticide use and surface water concentrations in the Sacramento River Watershed, California: U.S. Geological Survey Scientific Investigations Report 2004-5097, 28 p.

Orlando, J.L., McWayne, M., Sanders, C., and Hladik, M., 2013, Dissolved pesticide concentrations in the Sacramento-San Joaquin Delta and Grizzly Bay, California, 2011-12: U.S. Geological Survey Data Series 779, 24 p.

Natural Resources Conservation Service, 2013, Cropland data layer: accessed November 2013, at http://datagateway.nrcs. usda.gov/.

Panshin, S.Y., Dubrovsky, N.M., Gronberg, J.M, and Domagalski, J.L., 1998, Occurrence and distribution of dissolved pesticides in the San Joaquin River Basin, California: U.S. Geological Survey Water-Resources Investigations Report 98-4032, 88 p.
Sommer, T., Armor, C., Baxter, R., Breuer, R., Brown, L., Chotkowski, M., Culberson, S., Feyer, F., Gingas, M., Herbold, B., Kimmerer, W., Mueller-Solger, A., Nobriga, M., and Souza, K., 2007, The collapse of pelagic fishes in the upper San Francisco estuary: Fisheries, v. 32, p. 270 277.

Sommer, T., and Mejia, F., 2013, A place to call home-A synthesis of Delta Smelt habitat in the upper San Francisco Estuary, San Francisco Estuary and Watershed: Science, v. 11, no. 2,25 p.

U.S. Census Bureau, 2011, Census 2010: accessed May 2011, at http://www.census.gov/2010census/data/

U.S. Environmental Protection Agency, 1992, Definition and procedure for the determination of the method detection limit, revision 1.11: Code of Federal Regulations 40, Protection of the Environment, CFR Part 136, appendix B, p. 565-567.

U.S. Environmental Protection Agency, 2012, Office of pesticide programs aquatic life benchmarks: accessed March 28, 2012, at http://www.epa.gov/oppefedl/ecorisk_ ders/aquatic_life_benchmark.htm.

U.S. Geological Survey, 2006, Collection of water samples (ver. 2.0): U.S. Geological Survey Techniques of WaterResources Investigations, book 9, chap. A4, accessed April 14, 2014, at http://pubs.water.usgs.gov/twri9A4/.

U.S. Geological Survey, 2013a, National Water Information System, Streamflow data for Sacramento River at Freeport: accessed September 10, 2013, at http://waterdata.usgs.gov/ ca/nwis/uv? site_no $=11447650$.

U.S. Geological Survey, 2013b, National Water Information System, Streamflow data for San Joaquin River near Vernalis: accessed September 10, 2013, at http://waterdata. usgs.gov/ca/nwis/uv? site_no $=11303500$.

U.S. Geological Survey, 2014, National Land Cover Dataset 2011: accessed April 10, 2014, at http://www.mrlc.gov/.

Werner, I., Deanovic, L.A., Markiewicz, D., Khamphanh, M., Reece, C.K., Stillway, M., and Reece, C., 2010, Monitoring acute and chronic water column toxicity in the Northern Sacramento-San Joaquin Estuary, California, USA, using the euryhaline amphipod, Hyalella Azteca-2006 to 2007: Environmental Toxicity and Chemistry, v. 29, no. 10, p. 2190-2199

Weston, D.P., and Lydy, M.J., 2010, Urban and agricultural sources of pyrethroid insecticides to the Sacramento-San Joaquin Delta of California: Environmental Science \& Technology, v. 44, no. 5, p. 1833-1840.

Zhang, X., Starner, K., and Spurlock, F., 2012, Analysis of chlorpyrifos agricultural use in regions of frequent surface water detections in California, USA: Department of Pesticide Regulation, $12 \mathrm{p}$. 
Prepared by the Sacramento Publishing Service Center.

For more information concerning this report, contact:

Director

U.S. Geological Survey

California Water Science Center

6000 J Street, Placer Hall

Sacramento, CA 95819

dc_ca@usgs.gov

or visit our Web site at:

http://ca.water.usgs.gov 


\section{$\frac{\mathbb{2}}{3}$}

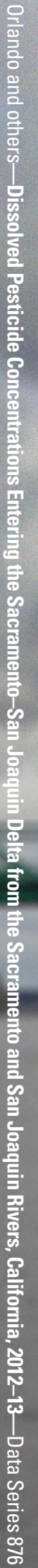

